\title{
An Assessment of Archeological Sites 41WY71 and 41WY72, Willacy County, Texas
}

D. William Day

Follow this and additional works at: https://scholarworks.sfasu.edu/ita

Part of the American Material Culture Commons, Archaeological Anthropology Commons, Environmental Studies Commons, Other American Studies Commons, Other Arts and Humanities Commons, Other History of Art, Architecture, and Archaeology Commons, and the United States History Commons

Tell us how this article helped you.

This Article is brought to you for free and open access by the Center for Regional Heritage Research at SFA ScholarWorks. It has been accepted for inclusion in Index of Texas Archaeology: Open Access Gray Literature from the Lone Star State by an authorized editor of SFA ScholarWorks. For more information, please contact cdsscholarworks@sfasu.edu. 


\section{An Assessment of Archeological Sites 41WY71 and 41WY72, Willacy County, Texas}

\section{Creative Commons License}

\section{(c) (1) (8)}

This work is licensed under a Creative Commons Attribution-NonCommercial 4.0 International License 
AN ASSESSMENT OF ARCHEOLOGICAL SITES 41 WY 71

AND 41WY72, WILLACY COUNTY, TEXAS

by

D. William Day

PRINCIPAL INVESTIGATOR: Elton R. Prewitt

REPORTS OF INVESTIGATIONS, NUMBER 17

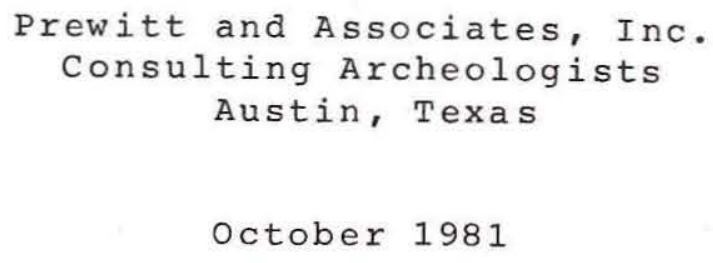


This report is submitted to Hidalgo County Drainage District No. 1 and Willacy County Drainage District No. 1, Edinburg, Texas, in partial fulfillment of letters of agreement dated May 1, 1981, and July 8, 1981. All work reported herein conforms to the provisions of state of Texas Antiquities Permit No. 278 issued by the Texas Antiquities Committee, Austin, Texas. 


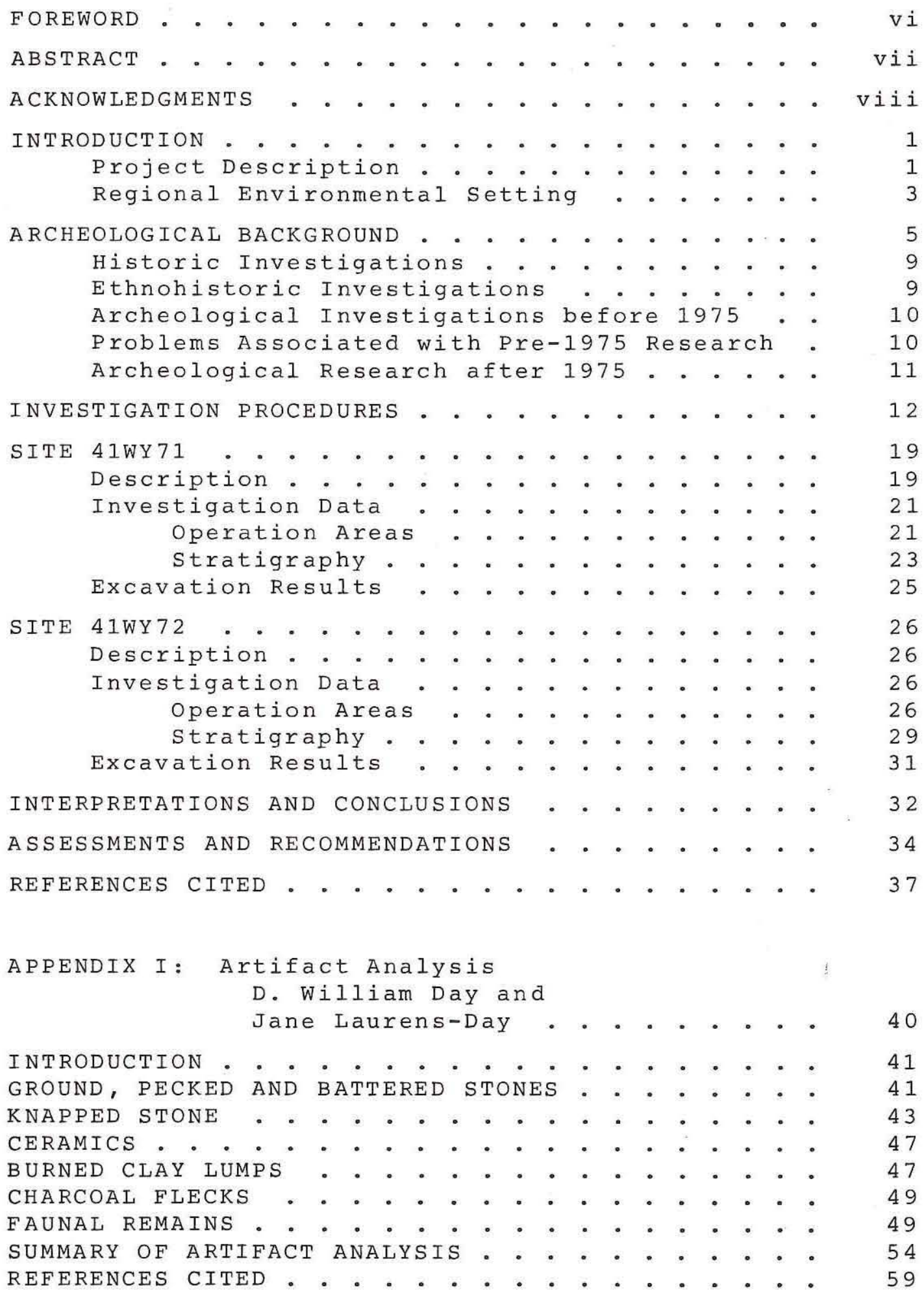


APPENDIX II: Faunal Analysis

Dale Winkler..... . . 60

TAXONOMY . . . . . . . . . . . . . . . . 61

CONDITION OF BONE . . . . . . . . . . . . . . 61

PALEOECOLOGY . . . . . . . . . . . . . . . . 61

APPENDIX III: Constant Volume Sample Analysis

Jane Laurens-Day and

D. William Day . . . . . 67

REFERENCES CITED . . . . . . . . . . . . . . . . . 74

\section{LIST OF FIGURES}

1. Project location map .. . . . . . . . 2

2. Site photographs . . . . . . . . . . . 4

3. Schematic of proposed machine-aided excavations. . . . . . . . . . . . . 14

4. Predicted site boundaries and investigation areas . . . . . . . . . . . 15

5. Site photographs . . . . . . . . . . 17

6. Site photographs . . . . . . . . .. 18

7. Site location map, 41Wr71... . . . . . 20

8. Cross sections and selected profiles, $41 W Y 71$. . . . . . . . . . . 24

9. Site location map, 41 wr 72 . . . . . . . . 27

10. Cross sections and selected profiles, 41 Wr72 . . . . . . . . . . 30

11. North Ditch realignment . . . . . . . . 36

12. Artifact illustrations . . . . . . . . . 42 
1. Observed flora and fauna in Willacy County . . 6

2. 41WY71: Operation area activity descriptions . . . . . . . . . . . 22

3. 41WY72: Operation area activity descriptions. . . . . . . . . . . 28

4. Summary of tertiary flakes by individual provenience and characteristics . . . . . . . . . . 45 45

5. Summary of lithic chips by individual provenience and characteristics . . . . . . 48

6. Identified terrestrial snail shell species by provenience. . . . . . . . . 50

7. Distribution of recovered materials at site 41 Wr71 . . . . . . . . . . . 51

8. Distribution of recovered materials at site 41 Wr72 . . . . . . . . . . 52

9. Major artifact groupings . . . . . . . . 54

10. Tertiary flakes . . . . . . . . . 56

11. Chips . . . . . . . . . . . . 57

12. Faunal list for 41 Wr71 and 41 Wr72 . . . . . 63

13. Occurrence of vertebrates in
41 WY 71 and 41 WY 72

14. Summary of material types by natural stratigraphic levels . . . . . . 69 
FOREWORD

This report prepared by D. William Day describes the results of continuing archeological investigations along the North Ditch in eastern Willacy County, Texas. Two sites discovered in the initial survey of the proposed channel alignment, 41WY71 and 41WY72, are discussed in this report. The findings at the sites support previous interpretations regarding temporary and semipermanent camps within the area. These are thought to represent a hunting and gathering adaptation which conforms to the Restricted Wandering model. A rather exciting find of seven obsidian or green glass flakes and chips at $41 \mathrm{WY} 72$ provides additional information regarding possible trade between the Rio Grande Delta peoples and groups in Mexico.

The local sponsors of the North Ditch project, represented by Judge Ramiro Guerra and $M r$. Ray Hunt of Edinburg, have exercised exemplary management procedures in dealing with the archeological resources in the project area. Following the testing of the two sites and the discovery that 41 Wy 72 contains regionally significant remains, the sponsors proposed that the project alignment be altered to avoid conflicts with the site. They also requested additional testing at both sites to insure the new alignment would accomplish the desired avoidance.

Judge Guerra and Mr. Hunt are commended for their concern with the prehistory of the Lower Rio Grande Valley, and their efforts on behalf of preserving the archeological resources are appreciated.

Elton R. Prewitt

Principal Investigator 


\section{ABSTRACT}

Test excavations at two prehistoric archeological sites in eastern Willacy county, Texas, were conducted by Prewitt and Associates, Inc. during May and July of 1981. The purpose of the investigations at sites $41 W Y 71$ and $41 W Y 72$ was to assess the potential eligibility of the sites for nomination to the National Register of Historic Places. It is concluded that site $41 \mathrm{WY} 71$ does not warrant nomination to the Register, but that site $41 W Y 72$ is of sufficient importance that it should be considered to be eligible for nomination to the Register.

Current work at these two sites has been accomplished under terms of an agreement with Hidalgo county Drainage District No. 1 and Willacy County Drainage District No. 1. Both sites will be affected by construction of the proposed North Ditch across the H.P. El Sauz Ranch. Based on the testing results, the alignment of the North Ditch was shifted southward to avoid conflicts with site 41 WY72. As a result, no significant impact should occur at that site.

The materials recovered indicate that site $41 \mathrm{WY} 71$ probably represents a temporary camp while site $41 W Y 72$ appears to represent a semipermanent site. Significant findings include two small ceramic sherds, seven pieces of obsidian or green glass, and a probable chert chipping station at site 41WY72. All the materials recovered are presumed to be Late Prehistoric in age. 


\section{ACKNOWLED GMENTS}

Many people have generously contributed their skills and energy toward the completion of this project. The author is indebted to Hidalgo County Water District No. 1, Willacy County Water District No. 1, and their representatives, Ray Hunt of Meldon and Hunt, Inc., Edinburg, and Hidalgo County Judge Ramiro Guerra, Edinburg. Administrative assistance was contributed by Dr. Laverne Herrington of the Texas Historical Commission in Austin.

A number of Willacy County residents provided assistance to the field crew. Robert Hommel of Hommel Construction, Inc. in Raymondville provided a backhoe and operation experience. Mr. and Mrs. Tex Foster provided housing and warm hospitality. Jim Drawe and the hands of the El Sauz Ranch provided friendly cooperation and concern for the safety of the crew.

Special studies were contributed by Jane LaurensDay, Leroy Werchan and Dale Winkler. Assistance in identifying some of the recovered materials was provided by Dr. Thomas R. Hester of The University of Texas at San Antonio and Dr. Raymond Neck of the Texas Parks and Wildlife Department, Austin.

The following personnel of Prewitt and Associates, Inc. contributed to this report. Cartography was provided by Sandra Hannum-Price, Kerza A. Prewitt and Margaret $A$. Howard. Linda Battles-Herron has contributed the artifact illustrations. Linda Nance has provided administrative assistance and typing of the draft and final report.

Jane Laurens-Day served as Assistant Archeologist in the field and provided welcome assistance during the laboratory analysis and reporting phases. Elton $R$. Prewitt served as Principal Investigator and edited the final report.

A special acknowledgment is offered to the crew, Barry Brookshire, Jan Guy, Margaret Howard, Vance Langley, Diana Lowery, Logan McNatt and Truett Roberts. The field crew was supplemented by Greg Hommel and Greg Wetegrove of Raymondville, and Jane Miller and John Nance of Austin.

The author expresses sincere appreciation to all of these people. 
An assessment of archeological sites 41 WY71 and 41WY72 was conducted by Prewitt and Associates, Inc. under the terms of an agreement with Hidalgo County Drainage District No. 1 and Willacy County Drainage District No. 1. The results of the investigations described in this report are in compliance with the provisions of State of Texas Antiquities Permit No. 278 issued by the Texas Antiquities Committee. The purpose of the investigations was to assess the eligibility of the two sites for nomination to the National Register of Historic Places.

Field investigations were accomplished during a 3-week period in May 1981. A crew of six persons, aided by two local laborers during the final week, carried out the excavations. D. William Day served as Project Archeologist and was responsible for the logistics and operations. Jane Laurens-Day was the Assistant Archeologist and shared the responsibilities for the completion of the project. Dale winkler contributed the analysis of the faunal materials and Leroy Werchan provided the soil analysis data. Elton R. Prewitt was the Principal Investigator.

A crew of five persons conducted an additional one week of excavations at the sites during the latter part of July 1981. This work was done in response to a slight alteration in the alignment of the North Ditch. The routing change was made in order to avoid the main portions of sites 41 WY71 and 41 WY 72 .

\section{PROJECT DESCRIPTION}

Archeological sites $41 W Y 71$ and 41 WY72 were recorded in the fall of 1980 during a surface survey along the proposed North Ditch alignment (Day, Laurens-Day and Prewitt 1981: 73-90). These two sites are located in Willacy County between Raymondville and Port Mansfield, Texas, on the H. P. El Sauz Ranch (Fig. 1).

The North Ditch extends from the outfall of the existing South Main Floodwater Channel (Point A) westward across the H. P. El Sauz Ranch and rejoins the existing channel segment $A-B$ approximately 2 kilometers east and south of willamar. The existing channel segment $A-B$ is included in Galveston District Corps of Engineers Permit No. 11374. The North Ditch is a routing change proposed by the local sponsors of the project. 
<smiles>C1CCC1</smiles> 
Willacy County is located in far southern Texas on the northern edge of the Rio Grande Delta. The following is a synthesis of environmental data reported earlier by Mallouf, Baskin and Killen (1977) and Day, Laurens-Day and Prewitt (1981). The two sites (41WY71 and 41 WY 72) lie within Environmental zone IV as defined in these reports.

The surface geology of a majority of willacy County consists of exposures of the late pleistocene Beaumont Formation. This formation is composed of clays, silts, sands and gravels with a maximum thickness of 275 meters (900 feet). Overlying the Beaumont Formation are Holocene and Recent abandoned channels, overbank muds, meander-belt sands, and eolian sands. Soil associations in the immediate project area consist of orelia, sodic Variant association, Raymondville association, and Raymondville-orelic sodic variants (Soil Conservation Service, Willacy County, Texas, ms. in preparation).

Surface topography in willacy county is gently undulating with a gradual slope seaward. Deltaic features, including interfluvial relict channel scars and multiple surface depressions characterize the region (Fig. 2). Elevations range from 1.5 meters (5 feet) above Mean sea Level (MSL) at the outfall (Point A) to 13.7 meters ( 45 feet) above MSL in western Willacy County. Intense flooding occurs during times of heavy rains. This is due to a lack of existing natural streams and allows floodwater to stand in low-lying areas for relatively long periods of time.

Climatic conditions are characterized as subtropical with intermittent spells of increased aridity on the Rio Grande Delta. Gulf of Mexico breezes flow southeasterly over the region approximately 40 percent of the time. North winds associated with polar air masses occur during the winter months.

Rainfall in the delta region averages 61.65 centimeters yearly with most falling during early fall and late spring. Thunderstorms occur approximately twentyfour days annually with a peak season during september and october. Tropical depressions and hurricanes are common from mid-summer to late fall. The Rio Grande Delta region has been affected by at least forty-one hurricanes between the years 1818 and 1980 (U.S. Army Engineer District, Galveston 1979: 11-12). The mean annual temperature is $24^{\circ} \mathrm{C}\left(74^{\circ} \mathrm{F}\right)$. The record high temperature is $42^{\circ} \mathrm{C}\left(107^{\circ} \mathrm{F}\right)$, and the record low temperature is $-11^{\circ} \mathrm{C}\left(12^{\circ} \mathrm{F}\right)$. 
Figure 2

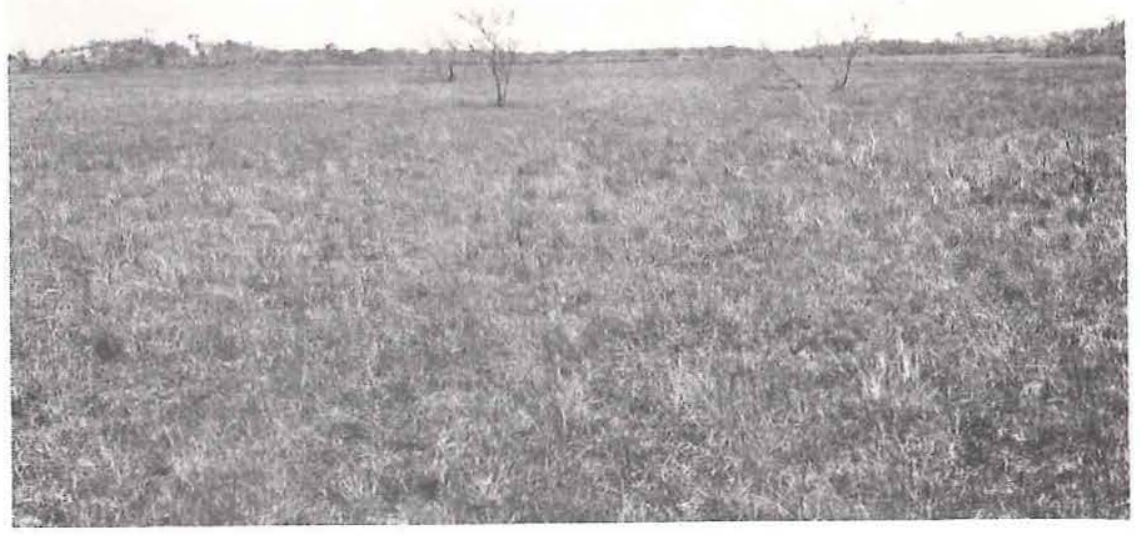

a. Looking north, view of relict channel scar between sites 41 WY71 and 41 WY 72 .

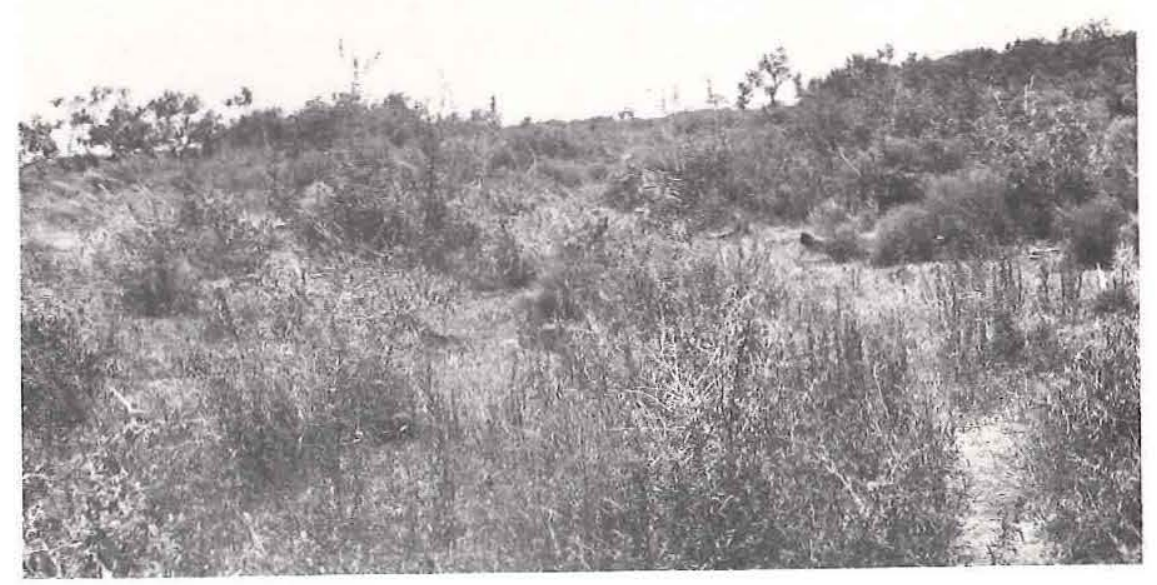

b. Looking north-northeast, view of natural levee on east side of relict channel scar, 41 WY71. 
Willacy County is included in the Tamaulipan biotic province (Blair 1950). Descriptive historic accounts indicate that the area was once a savannah having large open grass prairies. It has been reported that the region underwent a considerable increase in brush density from 1840-1900 (Inglis 1964).

Representative biota that were observed by the crew in the Rio Grande Delta region are listed in Table 1. Additional data are needed in order to reconstruct the past environments to allow for more detailed explanations of aboriginal adaptations and lifeways. However, reconstruction of past environments is hampered by two problems. First, the nature of the delta, having floodwaters flow over it from the west and seawater from the east, disallows accurate pollen and plant phytolith studies. Particles of such small size could be suspended in solution and carried for long distances thus producing invalid samples. Second, the immense volume of agricultural and developed land in the delta region has disrupted the natural biota. This makes it difficult to determine the early Historic-era baseline (e.g, see Inglis 1964) upon which prehistoric projections could be made.

Willacy County extends over approximately 411,536 acres and includes a portion of Padre Island. Cropland accounts for 49.47 percent of the total land, and rangeland accounts for 35.82 percent. Unproductive land is estimated at 6.98 percent, and surface water covers nearly 6.35 percent of the total land. Urban and developed land involves approximately 1.38 percent of the land (U.S. Army Engineer District, Galveston 1979: Table 53).

These figures provide a general trend of land use, although clearly they are somewhat dated. For instance, at least 22,000 additional acres of rangeland have recently been cleared for cultivation. Land used for urban development is increasing constantly. The clearing of land for cultivation and improved pastures, coupled with the growing urban developments, continues to have an adverse effect on the archeological record in Willacy County (Day, Laurens-Day and Prewitt 1981).

\section{ARCHEOLOGICAL BACKGROUND}

The regional archeological literature from Brooks, Cameron, Hidalgo, Jim Hogg, Kenedy, Starr, Willacy and zapata counties, Texas, and Tamaulipas, Mexico, have been thoroughly reviewed by Mallouf, Baskin and Killen (1977: 57-58). Rather than repeat their review, only a 
TABLE 1

OBSERVED FLORA AND FAUNA IN WILLACY COUNTY

\begin{tabular}{|c|c|c|}
\hline Family & Common Name & Scientific Name \\
\hline \multicolumn{3}{|c|}{ FLORA } \\
\hline Gramineae & $\begin{array}{l}\text { Silver bluestem } \\
\text { Seacoast bluestem } \\
\text { Buffelgrass } \\
\text { Hooded windmillgrass } \\
\text { Bermudagrass } \\
\text { Tropic sprangletop } \\
\text { Blue panicum } \\
\text { Panicgrass } \\
\text { Plains bristlegrass } \\
\text { Texas bristlegrass } \\
\text { Johnsongrass } \\
\text { Coastal sacahuista }\end{array}$ & $\begin{array}{l}\frac{\text { Andropogon }}{\text { Andropogon }} \frac{\text { saccharoides }}{\text { scoparius }} \\
\frac{\text { Cenchrus }}{\text { Chloris }} \frac{\text { cucullata }}{\text { Cynodon }} \\
\frac{\text { dactylon }}{\text { Leptochloa virgata }} \\
\frac{\text { Panicum }}{\text { Panicum }} \frac{\text { antidotable }}{\text { sp. }} \\
\frac{\text { Setaria }}{\text { Setaria }} \frac{\text { texana }}{\text { Sorghum }} \frac{\text { halepense }}{\text { Spartina }} \\
\text { Spartinae }\end{array}$ \\
\hline Fagaceae & Live oak & Quercus virginiana \\
\hline Ulmaceae & $\begin{array}{l}\text { Granjeno or spiny } \\
\text { hackberry }\end{array}$ & Celtis pallida \\
\hline Leguminosae & $\begin{array}{l}\text { Guajillo } \\
\text { Huisache } \\
\text { Catclaw } \\
\text { Blackbrush } \\
\text { Honeylocust } \\
\text { Texas ebony } \\
\text { Mesquite }\end{array}$ & $\begin{array}{l}\frac{\text { Acacia }}{\text { Acacia }} \frac{\text { berlandier }}{\text { farnesiana }} \\
\frac{\text { Acacia }}{\text { gregii }} \\
\frac{\text { Gleditais }}{\text { rigidula }} \\
\frac{\text { Pithecellobiuma }}{\text { Prosopis glandulosa }}\end{array}$ \\
\hline Rutaceae & Lime pricklyash & Zanthoxylum fagara \\
\hline Cataceae & $\begin{array}{l}\text { Devil's head } \\
\text { Texas prickly pear }\end{array}$ & $\frac{\text { Echinocactus }}{\text { Opuntia lindheimeri }}$ \\
\hline Verbenaceae & $\begin{array}{l}\text { Texas lantana } \\
\text { Texas vervain }\end{array}$ & $\frac{\text { Lantana horrida }}{\text { Verbena }}$ \\
\hline Compositae & $\begin{array}{l}\text { Sunflower } \\
\text { Gay-feather } \\
\text { Sowthistle }\end{array}$ & $\frac{\text { Helanthus }}{\text { Liatrus }} \frac{\text { cucumerifolius }}{\text { Sonchus }}$ \\
\hline
\end{tabular}

FAUNA

FRESHWATER AND

TERRESTRIAL

GASTROPODS

Aquatic Snails

Planorbidae

Helisoma trivolvis 
TABLE 1, continued

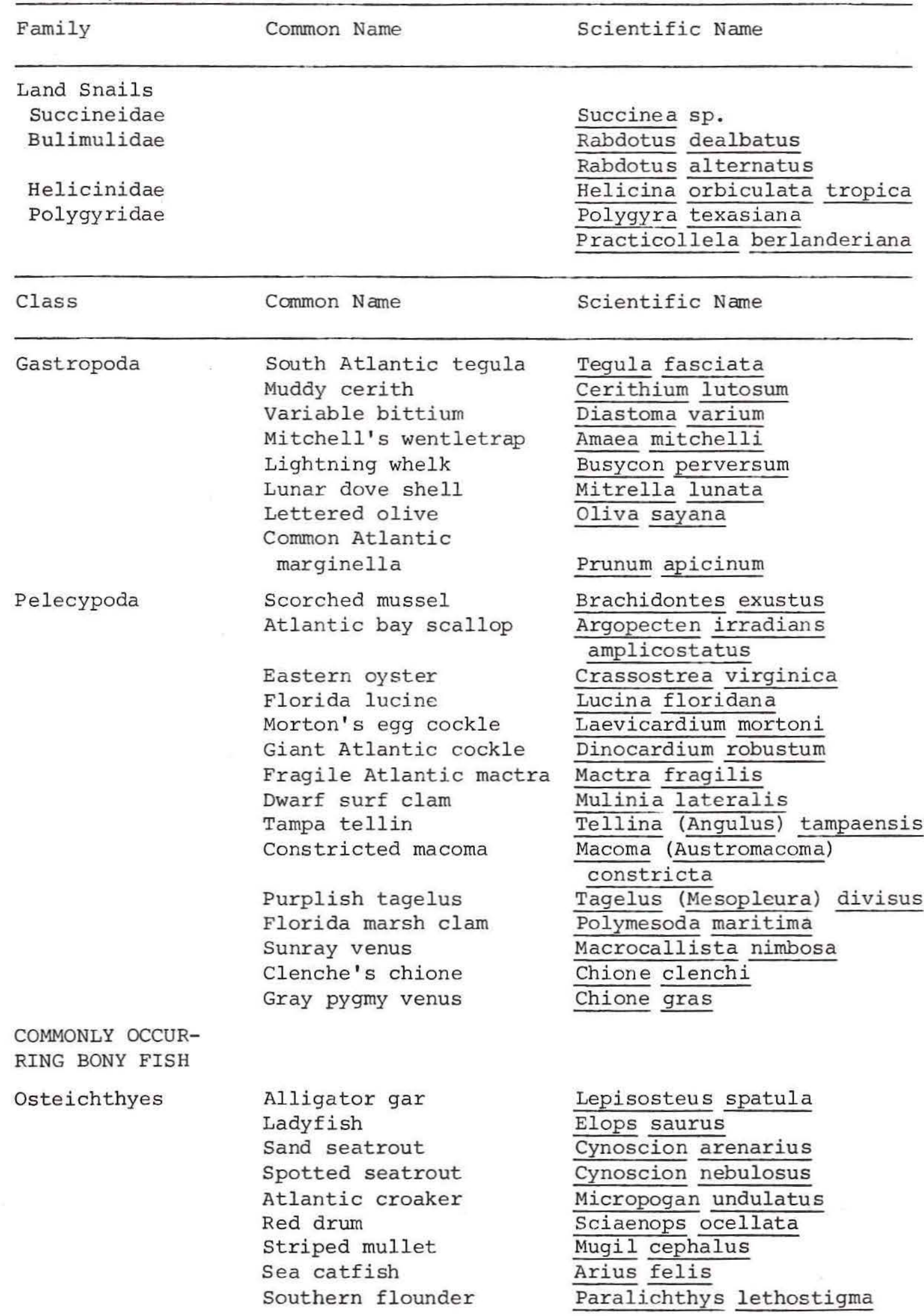


TABLE 1, continued

\begin{tabular}{|c|c|c|}
\hline Class & Common Name & Scientific Name \\
\hline Amphibia & $\begin{array}{l}\text { Bullfrog } \\
\text { Leopard frog } \\
\text { Rio Grande frog } \\
\text { Green tree frog } \\
\text { Couch's spadefoot toad } \\
\text { Gulf Coast toad }\end{array}$ & $\begin{array}{l}\frac{\text { Rana }}{\text { Rana }} \frac{\text { catesbeiana }}{\text { utricularia }} \\
\text { Syrrhophus cystignathoides } \\
\text { Hyla cinerea } \\
\text { Scaphiopus couchi } \\
\text { Bufo valliceps }\end{array}$ \\
\hline Reptilia & $\begin{array}{l}\text { Western box turtle } \\
\text { Red-eared turtle } \\
\text { Texas tortoise } \\
\text { Mesquite lizard } \\
\text { Prairie lizard } \\
\text { Keeled earless lizard } \\
\text { Black racer } \\
\text { Diamondback rattlesnake }\end{array}$ & $\begin{array}{l}\frac{\text { Terrapene }}{\text { Chrysemys }} \frac{\text { ornata }}{\text { scripta }} \\
\frac{\text { Gopherus }}{\text { berlandieri }} \\
\frac{\text { Sceloporus }}{\text { Sceloporus }} \frac{\text { gramicus }}{\text { undulatus }} \\
\frac{\text { Holbrookia }}{\text { Colubropinqua }} \\
\frac{\text { Crotalus atrox }}{\text { contrictor }}\end{array}$ \\
\hline Aves & $\begin{array}{l}\text { Eared grebe } \\
\text { Great blue heron } \\
\text { Cattle egret } \\
\text { Mallard } \\
\text { Turkey vulture } \\
\text { Harris hawk } \\
\text { Wild turkey } \\
\text { Killdeer } \\
\text { Laughing gull } \\
\text { Ground dove } \\
\text { Roadrunner } \\
\text { Groove-billed ani } \\
\text { Barn owl } \\
\text { Scissor-tailed } \\
\text { flycatcher } \\
\text { Mockingbird }\end{array}$ & $\begin{array}{l}\frac{\text { Podiceps }}{\text { Ardea herodias }} \\
\frac{\text { Bubulcus }}{\text { Anas platyrhynchos }} \\
\frac{\text { Cathartes }}{\text { Parabuteo }} \frac{\text { aura }}{\text { unicinctus }} \\
\frac{\text { Meleagris }}{\text { gallopavo }} \\
\frac{\text { Laradradris atricilla }}{\text { Columbia gallina }} \\
\frac{\text { passerina }}{\text { Geococcyx }} \\
\frac{\text { Califotophaga }}{\text { Tyto alba }} \\
\frac{\text { Mulcirostris }}{\text { Mimus polyglottos }} \\
\end{array}$ \\
\hline Mammalia & $\begin{array}{l}\text { Opossum } \\
\text { Hognose skunk } \\
\text { Coyote } \\
\text { Bobcat } \\
\text { Collared peccary } \\
\text { or javelina } \\
\text { Spotted ground squirrel } \\
\text { South Texas pocket } \\
\text { gopher } \\
\text { Hispid cotton rat } \\
\text { South Plains woodrat } \\
\text { California jackrabbit } \\
\text { Eastern cottontail } \\
\text { rabbit } \\
\text { White-tailed deer }\end{array}$ & $\begin{array}{l}\frac{\text { Didelphus }}{\text { Conepatus }} \frac{\text { marsupialis }}{\text { leuconatus }} \\
\frac{\text { Canis }}{\text { Lytran }} \frac{\text { rufus }}{\text { Dicotyles }} \\
\frac{\text { Spermophilus }}{\text { uspilosoma }} \\
\frac{\text { Geomys personatus }}{\text { Sigmodon }} \frac{\text { hispidus }}{\text { Neotoma micropus }} \\
\frac{\text { Lepus }}{\text { californicus }} \\
\frac{\text { Sylvilagus }}{\text { Odocoileus }} \frac{\text { floridanus }}{\text { virginianus }}\end{array}$ \\
\hline
\end{tabular}


brief statement of the archeological investigations conducted in the region is presented. Particular attention is given to the data base provided by investigations conducted prior to 1975, and some of the problems associated with this work are discussed. Recent (after 1975) literature that bears on the investigations accomplished at sites 41 WY71 and 41 WY72 is also reviewed.

\section{HISTORIC INVESTIGATIONS}

Historic archeological investigations in the region have been concentrated in Cameron and Hidalgo counties, Texas, and on nineteenth century Mexican War and Civil War military sites. Archeological research has been carried out at the Mexican War site of Resaca de la Palma (Collins, Hester and Ellezy n.d.) and at Palo Alto Battlefield (Baxter and Killen 1976). Salvage-oriented work by Corbin and Tunnell (n.d.) and Boggs (n.d.) were accomplished at the Civil War site of Brazos Santiago Depot. More recent archeological investigations in Hidalgo and Willacy counties have included summarized archival historic data (Mallouf, Baskin and Killen 1977; Victor 1981).

\section{ETHNOHISTORIC INVESTIGATIONS}

Ethnohistoric research is an important avenue of investigation into past lifeways. However, very little ethnohistoric research has been accomplished in the region. It is not clear if this is due to a lack of data sources or if the area has been ignored by ethnohistorians. Saldivar (1943) has documented the locations of fifty-six historic aboriginal groups in northern Tamaulipas, Mexico, and in the southernmost region of Texas near the Rio Grande. However, very little descriptive data concerning the lifeways of the groups is provided by saldivar.

\footnotetext{
Hester (1981) has briefly reviewed the ethnohistoric data for southern Texas. He indicates that Ruecking (1955) and Newcomb (1961) have erroneously named the aboriginal people of the area "Coahuiltecans" and that an "ethnographic mythology" describing their lifeways has developed. Hester suggests that recent investigations by T. N. Campbell (1975, 1977) and Ives Goddard (1979) dispell the previously held notions of Coahuiltecan lifeways. Their data indicates that there were a number of cultural groups having diverse languages and that very little is known about their lifeways (Hester 1981: 120). Clearly, further ethnohistoric investigations are needed in the region.
} 
ARCHEOLOGICAL INVESTIGATIONS BEFORE 1975

A number of archeological investigations have been accomplished in the general southern Texas region. These investigations primarily have been directed toward reporting site locations and descriptive artifact analyses, with only generalized discussions of hunter/ gatherer economies. Four named cultural units have been proposed.

Near the mouth of the Rio Grande, two previously proposed cultural units are the Brownsville Complex and the Barril Complex (MacNeish 1947, 1958). They are believed to represent a Neo-Archaic adaptation which occurred in late prehistoric times. The artifact assemblage from the Brownsville Complex has an increase in frequency of stone tubes, and the Barril Complex has an increase in frequency of marine shell projectile points (MacNeish 1958: 186-192; Jackson 1940: 121). These two differing artifact frequencies serve as the distinguishing factor between the cultural units.

Two cultural units are reported from the Falcon Reservoir area near southwestern Hidalgo County. They are the Falcon Focus, generally believed to represent an Archaic culture, and the Mier Focus which is believed to represent a late Archaic culture that continues into late prehistoric times.

The validity of these two foci are controversial. Suhm, Krieger and Jelks (1954: 136-141) characterize the Falcon and Mier foci as long periods of stable adaptations with little cultural change. More recent investigations in the Falcon Reservoir region suggest cultural diversity within small geographic areas (Nunley 1971: iv-v; Nunley and Hester 1975: 95; Mallouf, Baskin and Killen 1977: 87).

In addition to the above-mentioned four cultural units, limited materials suggest that Rockport Focus people may have exploited resources as far south as Willacy County (Mallouf, Baskin and Killen 1977: 88).

\section{PROBLEMS ASSOCIATED WITH PRE-1975 RESEARCH}

More recent archeological investigations in Hidalgo and Willacy counties indicate that parts of the previous research is problematical (Day, Laurens-Day and Prewitt 1981). First, the majority of research accomplished in the southern counties of Texas and northeastern Mexico has relied on archeological survey and the random collection of surface-exposed cultural debris although excavation-derived data have been reported from central 
and south Tamaulipas, Mexico and the Falcon Reservoir area. Salvage-oriented excavations have been accomplished in Cameron and Hidalgo counties, but these have concentrated on aboriginal and historic cemetery sites. The earlier research does not offer substantial excavated data from the variety of occupation sites, and this lack of information obtained through excavation raises doubts concerning the reliability of the conclusions based on many of those works.

Second, many of the archeological reports do not define environmental zones. The data are recorded under nonspecific terms such as south Texas, South Central Texas, Coastal Texas, South Texas Monte, Rio Grande Plain, or the Rio Grande Delta. These terms do not allow for the varying environs in the region and serve to mask the cultural diversity which may be present.

Third, the use of named cultural units as an appropriate taxonomic system is controversial. The controversy is based largely on the lack of excavationderived data from a representative sample of campites.

\title{
ARCHEOLOGICAL RESEARCH AFTER 1975
}

\begin{abstract}
Recent archeological investigations have offered a different approach to the regional archeological research. Mallouf, Baskin and Killen (1977) accomplished a predictive assessment in portions of Hidalgo and Willacy counties utilizing both probability and judgment sampling techniques. They stress the significance of environmental and geologic features and site locational data, giving attention to La Sal Vieja, the Norias sand lobe and eolian depressions. They hypothesize that the natural features provide an important source of potable water, attraction of game and vegetable resources, and they further describe possible hunting strategies that could have been used by aboriginal peoples.
\end{abstract}

Hester (1981: 119-126) declares that data exist which indicate intraregional cultural diversity. He draws attention to the spatial and temporal distribution of resources in the area, illustrated by "high-" and "low-" density resource areas. High-density resource areas probably reflect the degree to which groups could develop resource exploitation strategies based on seasonal cycles, the frequency they could reuse favored campsites, and the frequency of mobility necessary to obtain desired resources.

Day, Laurens-Day and Prewitt (1981) accomplished a cultural resource survey, limited testing and assessments from south-central Hidalgo County eastward across 
Willacy County to the Laguna Madre. Their work is an expansion of the previous investigations accomplished by Mallouf, Baskin and Killen (1977). A predictive site location model was developed prior to the commencement of fieldwork and was successfully tested in the field. Although the terminology is slightly different, the model is derived from the Restricted wandering model commonly used to describe hunting and gathering cultures (Beardsley et al. 1956: 136-138).

The model defines a settlement pattern that consists of semipermanent and temporary campsites. Semipermanent camps are sites which were occupied for two or more weeks and up to as long as one season or more. It is not believed that food and water resources were abundant enough to allow for multiple-season or yearround use at a given site. These camps are expected to have been situated on elevated land above the areas prone to flooding. These camps could have supported an extended family or other cultural unit greater in size than a nuclear family.

Temporary camps are sites which were occupied for one or two days and up to two weeks. These camps were strategically selected for the purpose of exploiting desired resources that could not be obtained in the immediate vicinity of the semipermanent camps. Temporary camps were probably placed both in the preferred higher elevations and in less desirable locations prone to flooding. Presumably, these camps were occupied by small groups such as foraging or hunting parties, or nuclear families. The resources could have been collected for on-the-spot consumption or for transportation to a semipermanent camp and distribution among the group or storage for later use.

\section{INVESTIGATION PROCEDURES}

The test excavations at sites 41 WY71 and 41 WY 72 were designed to provide sufficient information to assess their eligibility for nomination to the National Register of Historic Places. Testing was confined to the North Ditch right-of-way and consisted of both machine-aided and hand excavated units. The excavations were directed toward obtaining information relative to:

(1) Definition of site size;

(2) Horizontal and vertical site boundaries;

(3) Site integrity; 
(4) Recognition of cultural features or isolatable activity areas; and

(5) Determination of site age by absolute or relative chronology.

An investigative strategy which combined machineaided and hand excavated units was devised to gather pertinent data for the assessments. The buried nature of the sites and the difficulty of hand excavation units suggested the usefulness of machine-assisted excavations. A grid of ranked priority trenches to be excavated with a backhoe were planned as a means of identifying the horizontal and vertical extent of the sites. These trenches, originating on the boundaries of the investigation area (first priority trenches) and converging inward (second and third priority trenches), were to be excavated as needed to locate the edges of the sites (Fig. 3). Hand excavated units were to be located on the basis of the results of the trenching operations and were intended to provide controlled data.

A known survey point was located on the southern margin of the North Ditch easement west of 41 WY72. This point served as a reference from which an arbitrary grid was established on the two sites (Fig. 4). No additional known survey points could be found in the vicinity of 41 WY71 and 41WY72. Consequently, an arbitrary baseline which approximates the easement's southern margin was established. Arbitrary intervals along the baseline were selected and transects oriented magnetic north were established across the right-of-way. An additional transect oriented east-west was established near the center of the investigation areas at both sites.

Locations for the 10-meter-long rank-ordered trenches were selected and staked along the north-south and east-west transects. The first two trenches (Operation Areas I and II, Trenches 1 and 2 on 41WY72) were excavated from the baseline and were oriented north. All backhoe excavations were monitored. No artifacts were recovered during the excavation of the first two trenches even though they were intentionally located in the vicinity of the previous year's subsurface probe which resulted in the identification of the site. It seemed somewhat unlikely that the site could be restricted to such a small area; an alternative explanation for the lack of debris was that perhaps the materials were so small and thinly distributed that they simply were not visible in the excavated matrix or the trench walls. 


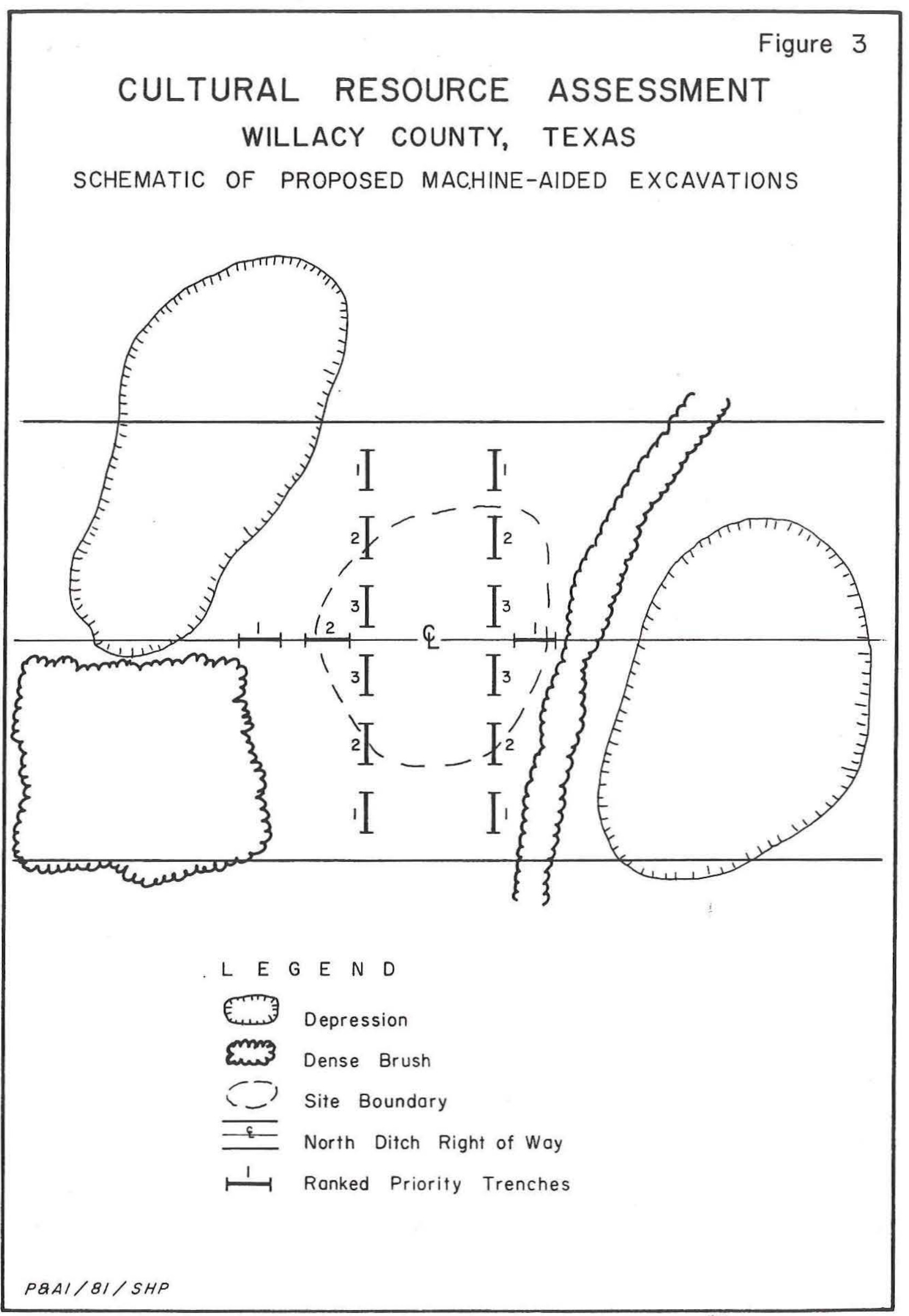




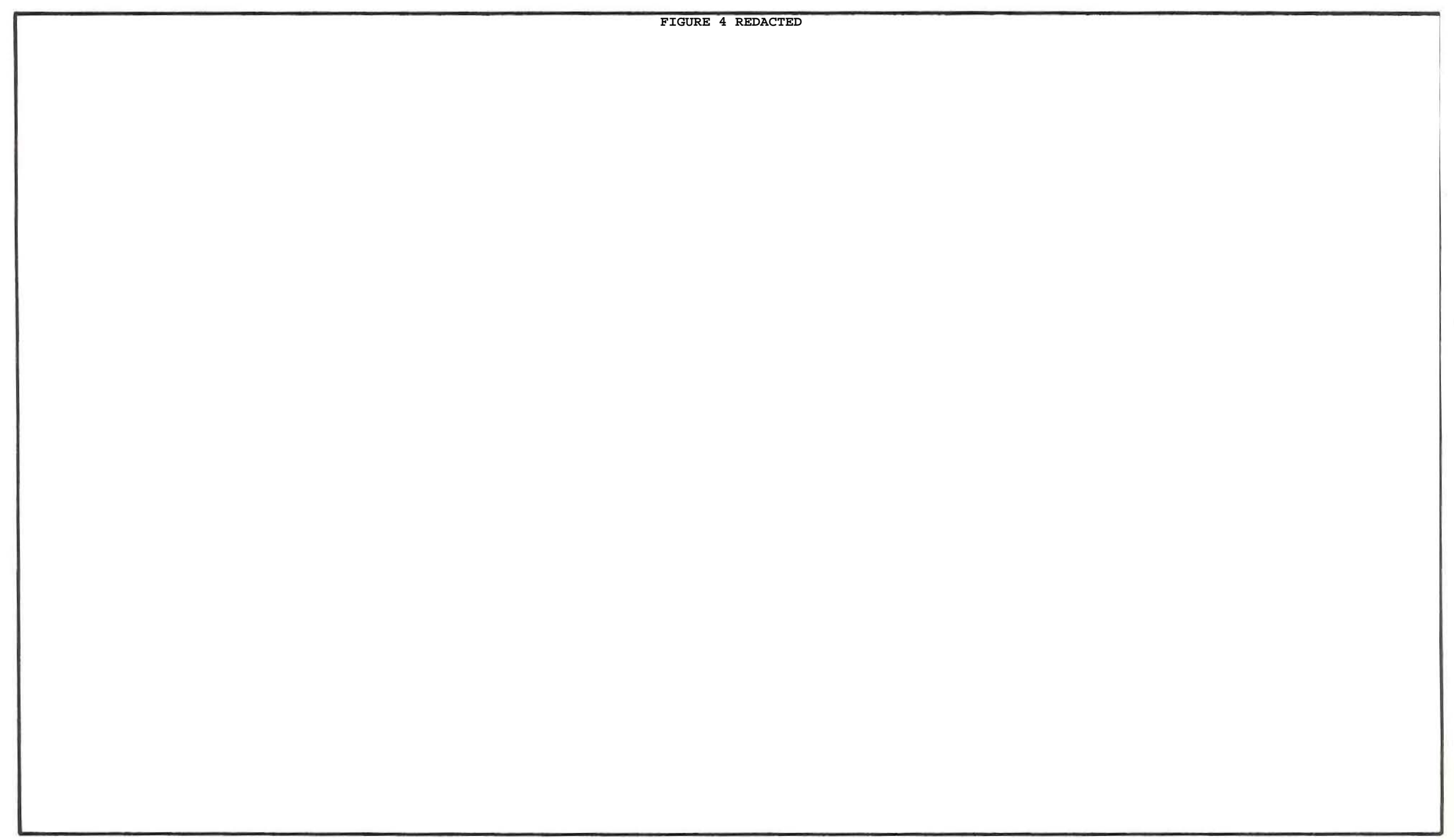


In order to test this explanation, a $2 \times 2$-meter controlled unit (Operation Area II, Excavation Unit 2, 41WY72) was excavated near Trench 2. The sterile topsoil was removed by the backhoe and hand excavations were in 20-centimeter arbitrary levels. Cultural materials were recovered from approximately 70 centimeters below ground surface to a maximum depth of 2.25 meters below surface. This suggested that trenching might not be sufficient to recognize site boundaries. The investigation strategy was revised accordingly.

The revised strategy called for the continued use of the backhoe to excavate the 10-meter trenches defined as first priority trenches at each site. This was necessary to provide a rapid means of identifying and recording the natural stratigraphy across the investigation areas. Further, since it appeared that the cultural materials were difficult to locate in machineexcavated matrix, this situation provided an opportunity to evaluate the usefulness of machine-assisted excavations in the region. In addition to the first priority trenches on the two sites, the backhoe was used to strip sterile overburden in preparation for the excavation of $1 \times 1$-meter units.

Investigations at each site were recorded as operation areas. Each operation area consists of a 10-meter trench and/or a test excavation unit (Figs. 5 and 6). Individual trenches and excavation units were numbered the same as the operation area in which they were excavated. For Example, Operation Area I on site 41WY71 contains Backhoe Trench No. 1 and Excavation Unit No. 1, and Operation Area II contains Backhoe Trench No. 2 and Excavation Unit No. 2. The use of the numbered "Operation Area" designation provides a summary means of discussing the multiple test units and techniques utilized during excavation. Detailed information concerning each operation Area is provided under the appropriate site heading.

Test units consisted of 1x1-meter units excavated in 20-centimeter arbitrary levels except for Unit 2 , Operation. Area II, on 41WY72 which was begun as a 2x2-meter unit. A temporary datum was established at the highest corner of each test unit and the elevation was recorded in relation to the arbitrary site datum. A string line, line level and hand tape were used to determine relative elevations below the surface. All excavated matrix was sieved through $\frac{1}{4}$-inch hardware cloth. Cultural materials collected were placed in bags with appropriate provenience labels. Unit level records were maintained for each level, and general notes were taken of the day-to-day operations. A representative profile of each excavation was drawn to scale to 
Figure

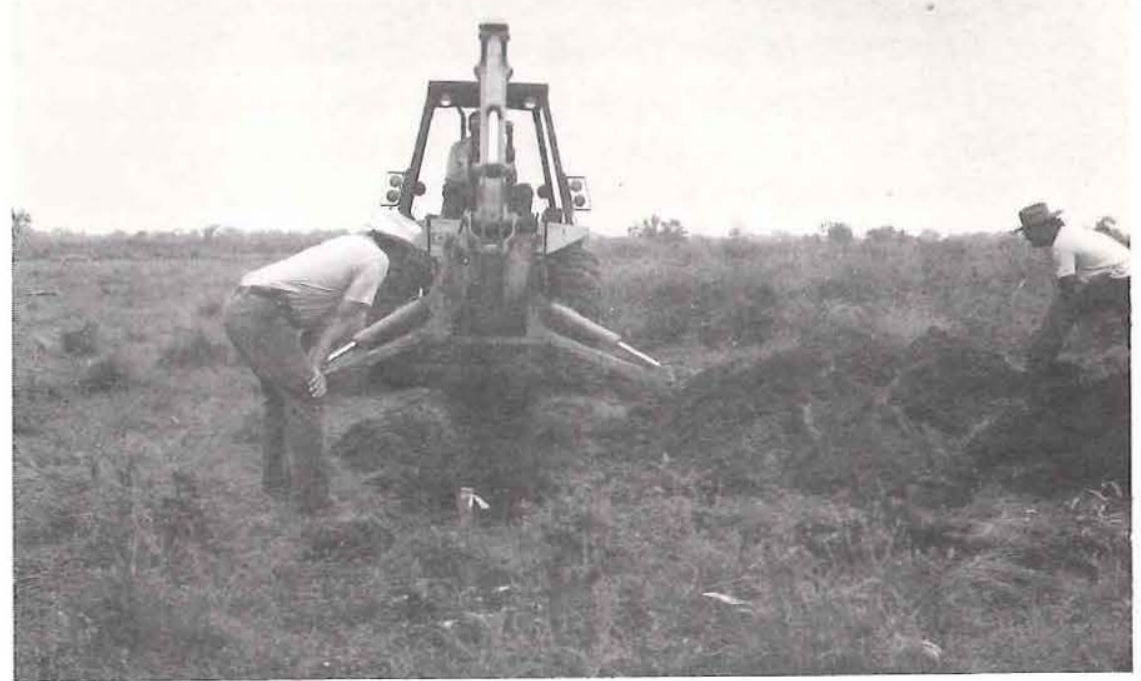

a. Site 41 WY72 looking north. Backhoe excavation and monitoring of Operation Area IV, Trench 4.

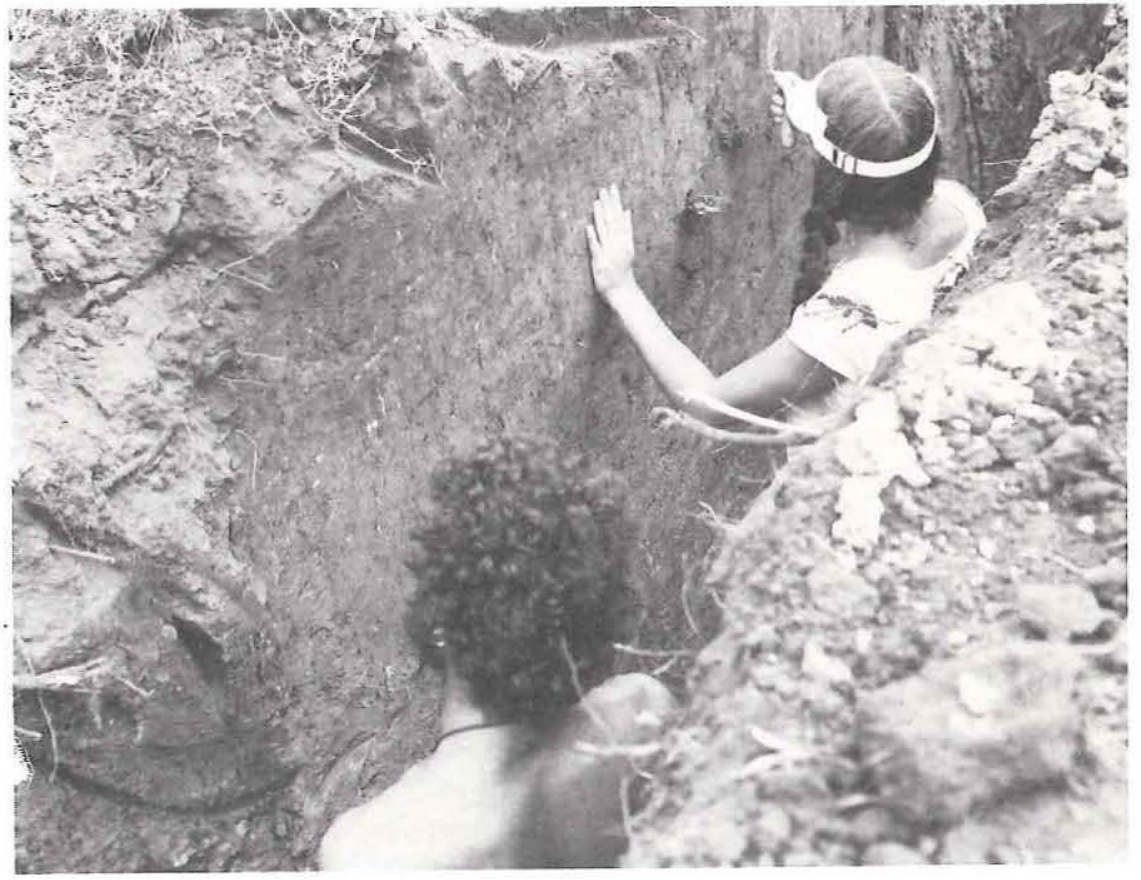

b. Site 41 WY 72 , west wall profile cleaning at Operation Area IV, Trench 4. 
Figure

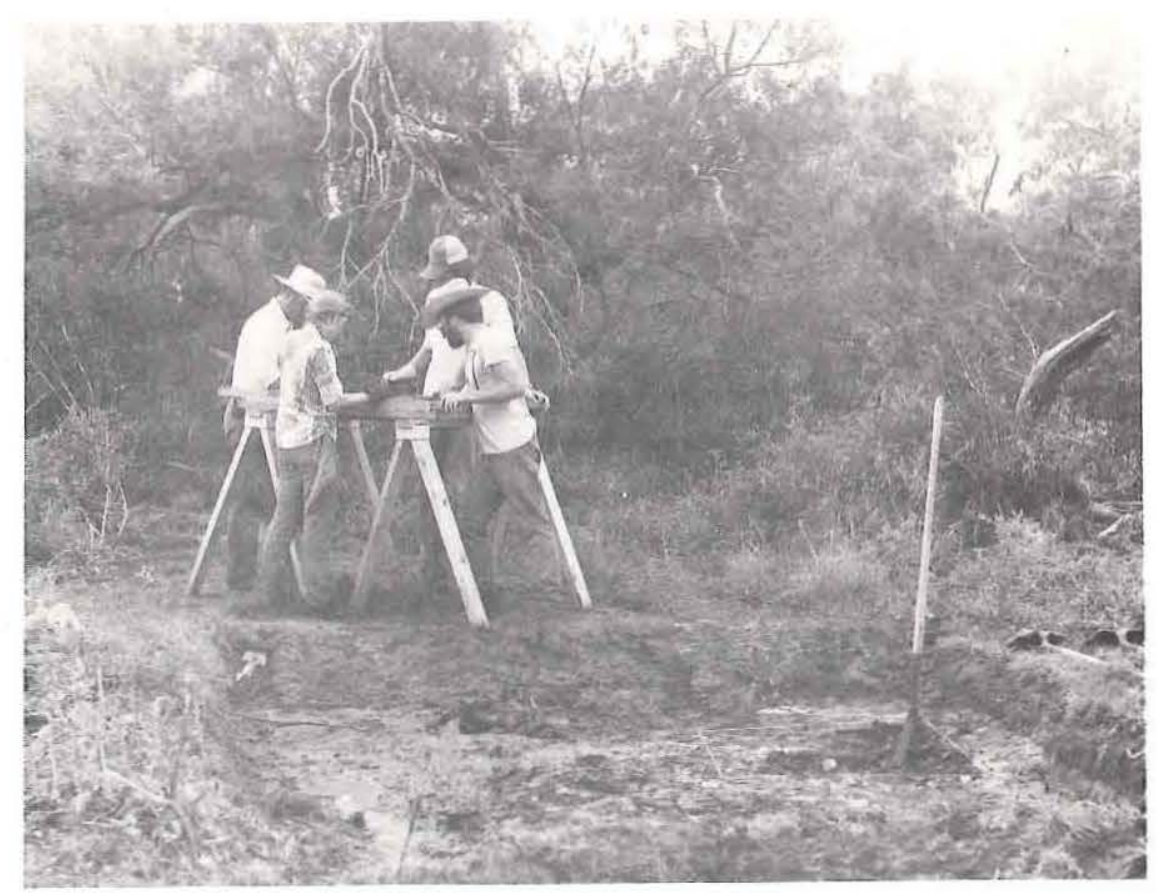

a. Site 41WY71, looking east. Beginning excavations at Operation Area I, Excavation Unit 1.

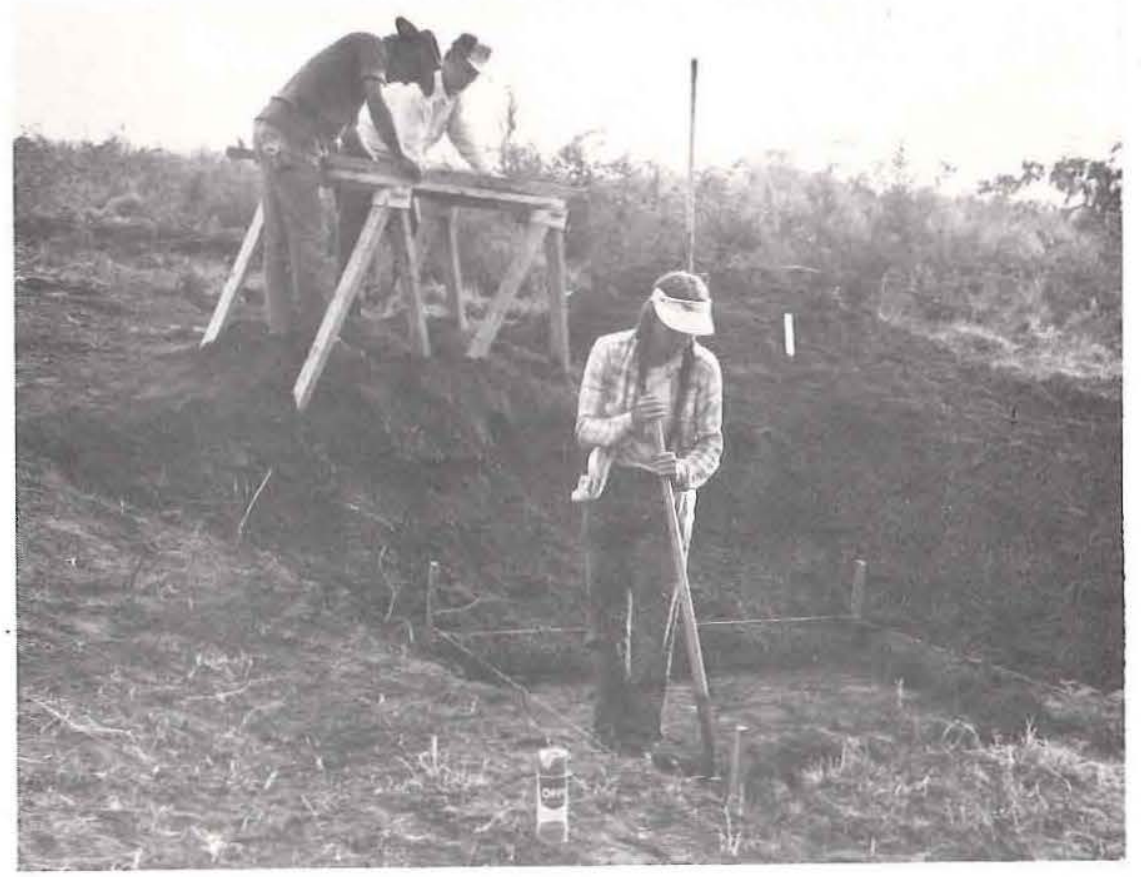

b. Site $41 W Y 72$, looking northeast. Beginning excavations at Operation Area II, Excavation Unit 2. 
indicate the natural strata encountered during excavation. Soil samples (one-half of a 16-pound paper bag) were collected from each stratum in each excavation unit.

In addition to the trenches and hand excavation units, one stratigraphic test was dug with the backhoe at each site. These units were about 3 meters by 1.5 meters and extended to a maximum depth of 4.25 meters on 41 WY 71 and 3.40 meters on 41 WY72. These units were excavated to provide a more complete view of the stratigraphy.

All artifacts and materials recovered were sent to the laboratory of Prewitt and Associates, Inc. in Austin where they were washed, labeled and catalogued. A constant volume sample of approximately 800 cubic centimeters was removed from the soil samples. The constant volume matrix was sieved through $1 / 32$ nd-inch wire mesh. Materials retrieved were examined under a binocular microscope at $60 \mathrm{x}$ and $100 \mathrm{x}$ power (see Appendix III). The remaining soil from each sample was analyzed to determine the color, $\mathrm{pH}$ and texture.

During the processing of the collected materials and report preparation, an alternative alignment of the North Ditch was proposed. The realignment shifts the channel south of the known extent of 41 WY71 and 41 WY72. This resulted in spending an additional week excavating four 1xi-meter test hand excavation units (Operation Areas VIII and IX, Units 8 and 9, 41WY71; Operation Areas VIII and IX, Units 8 and 9, 41WY72). These units were excavated without the assistance of a backhoe. The same excavation and recording procedures described above were used. Data gathered during the additional excavations are included in this report.

SITE 41 WY 71

\section{DESCRIPTION}

Site 41 WY $7 \underset{\text { TEXT }}{\text { is }}$ situated on the front slope of a
natural levee

The floral cover is dominated by thorny brush and shrubs ranging from 1.0 to 1.5 meters high. The brush 


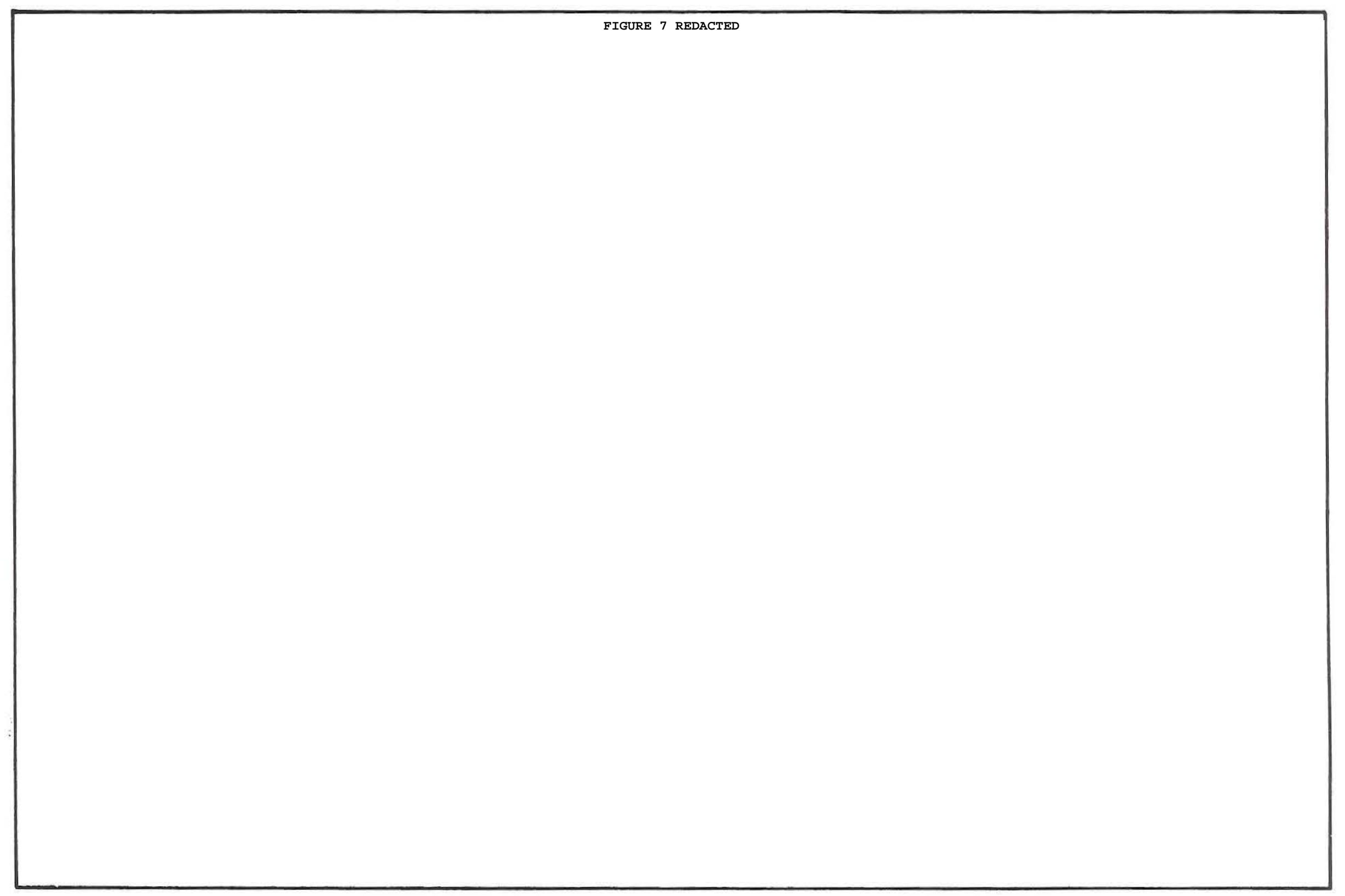


is recent regrowth which has emerged following clearing operations designed to facilitate pasture improvement. small open areas of bermudagrass are interspersed throughout the brush on the levee. Several isolated trees rise above the brush, and a dense stand of mesquite trees (approximately 100 meters east/west and 120 meters north/south) is located on the southern portion of the investigation area. A line of mesquite trees forms a plant species barrier which divides the brush from the salt-tolerant grasses that cover the floor of the relict channel.

\section{INVESTIGATION DATA}

\section{Operation Areas}

Table 2 contains a summary of the activities accomplished within the nine operation Areas of site 41WY71. Included is information concerning (1) the specific numerical designation of each excavation, (2) the types of excavations accomplished in each area (Backhoe Trenches and Test Units), (3) the dimensions of each excavation, (4) the number of profiles drawn, and (5) the locations of the wall profiles. Six backhoe trenches and seven test units were excavated at site $41 \mathrm{WY} 71$.

The backhoe trenches were excavated in Operation Areas I through VI and are oriented approximately north-south. Each trench is approximately 10 meters long and ranges in depth from 1.67 meters (Trench 6) to 2.2 meters (Trench 2) below ground surface. One 2-meter wide profile of one wall was drawn to scale in each trench.

The test units were excavated in Operation Areas I-IV and VII-IX. Test Units $1-4$ are associated with Trenches 1-4. Test Unit 7 was excavated near the center of the investigation area. Test Units 8 and 9 were placed near the southern extent of the site within the planned realignment of the North Ditch. Specific dimensions of each level removed from the test units are provided in Table 2 and include a designation of those levels that were excavated with the backhoe (b). The levels excavated by the backhoe represent the arbitrary removal of sterile overburden. They range in depth from 0-26 centimeters (Test Unit 4 ) to 0-34 centimeters (Test Units 1 and 2). Ensuing levels were excavated in 20-centimeter arbitrary increments. One wall of each test unit was drawn to scale. 
TABLE 2

41WY71: OPERATION AREA ACTIVITY DESCRIPTIONS

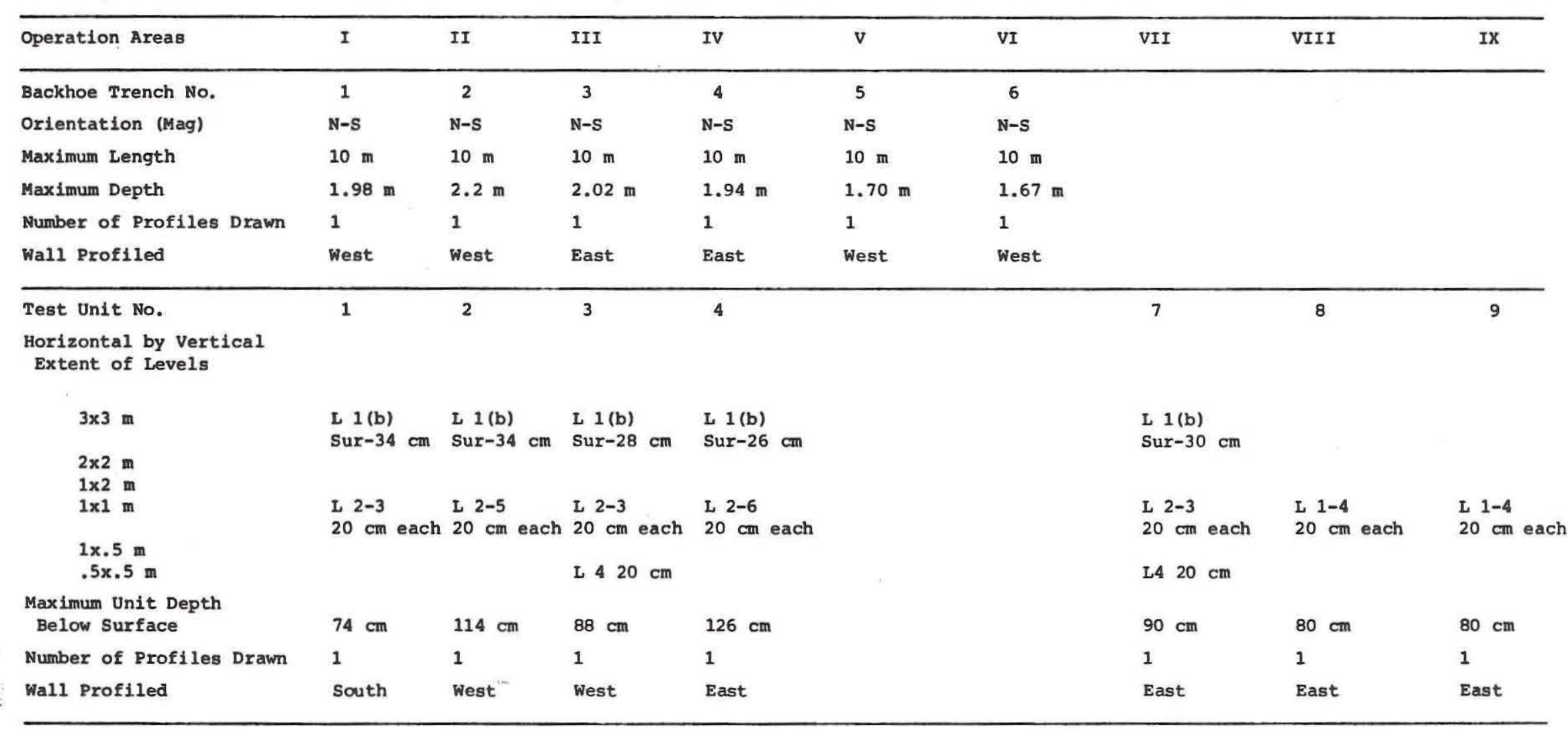

(b) $=$ level excavated by backhoe; $\mathrm{m}=$ meters; $\mathrm{cm}=$ centimeters; $\mathrm{L}=$ arbitrary level. 
The six strata recognized at 41 WY 71 are described in this section. The descriptions are presented in the order of encounter; that is, the surface stratum is described first and the lowest stratum last. Color notations refer to standard Munsell Color designations (Munsell Color Co. 1975). Figure 8 indicates generalized cross sections and selected profiles from 41 WY 71.

\section{Stratum I}

Stratum I is composed of a very dark brown (10YR $2 / 2$ ) to a dark grayish-brown (10YR 4/2) dry compact soil. The pH is slightly acid (6.8) at operation Area VII and slightly basic (7.5-8.0) at operations Areas II and IV. The stratum is 12 to 20 centimeters thick and contains a surface mat of grass, shrub and brush roots. Textural variation is from a silty clay (IA) to a fine sandy loan (IB).

\section{Stratum II}

Stratum II is a very dark brown (10YR 4/2) to a dark grayish-brown (10YR 4/2) dry compact soil which becomes slightly more moist and a little less compact near the bottom. The $\mathrm{pH}$ is slightly basic ( 7.8 to 8.0$)$ throughout. The stratum is approximately 35 centimeters thick and contains less root intrusion than stratum I although rotted tree roots were encountered. Texture varies from a clay loam (IIA) to a sandy clay loam (IIB) to a silty clay loam (IIC). In addition, IIA and IIB contain brownish-yellow (10YR 6/8) to yellow (10YR $7 / 8$ ) mottling.

\section{Stratum III}

Stratum III varies from a dark yellowish-brown (1OYR 4/4) to a yellowish-brown (1OYR 5/4) in IIIA and is brown (1OYR $4 / 3$ to 1OYR $5 / 3$ ) in IIIB and IIIC. The matrix is moist and compact, averages approximately 35 centimeters thick, and contains rotted tree roots and root stains. The $\mathrm{pH}$ is slightly basic (7.8-8.0) throughout. Textural variation is from a silty clay (IIIA) to a sandy clay loam (IIIB) to a silty clay loam (IIIC).

\section{Stratum IV}

Stratum IV is composed of a dark yellowish-brown (1OYR 4/4) to a yellowish-brown (10YR 5/4) moist compact soil. The pH is slightly basic (7.8-8.0) throughout. The stratum averages approximately 70 centimeters thick and contains a small amount of taproot stains. The 


\section{CULTURAL RESOURCE ASSESSMENT}

$41 W Y 71$

CROSS SECTIONS \& SELECTED PROFILES
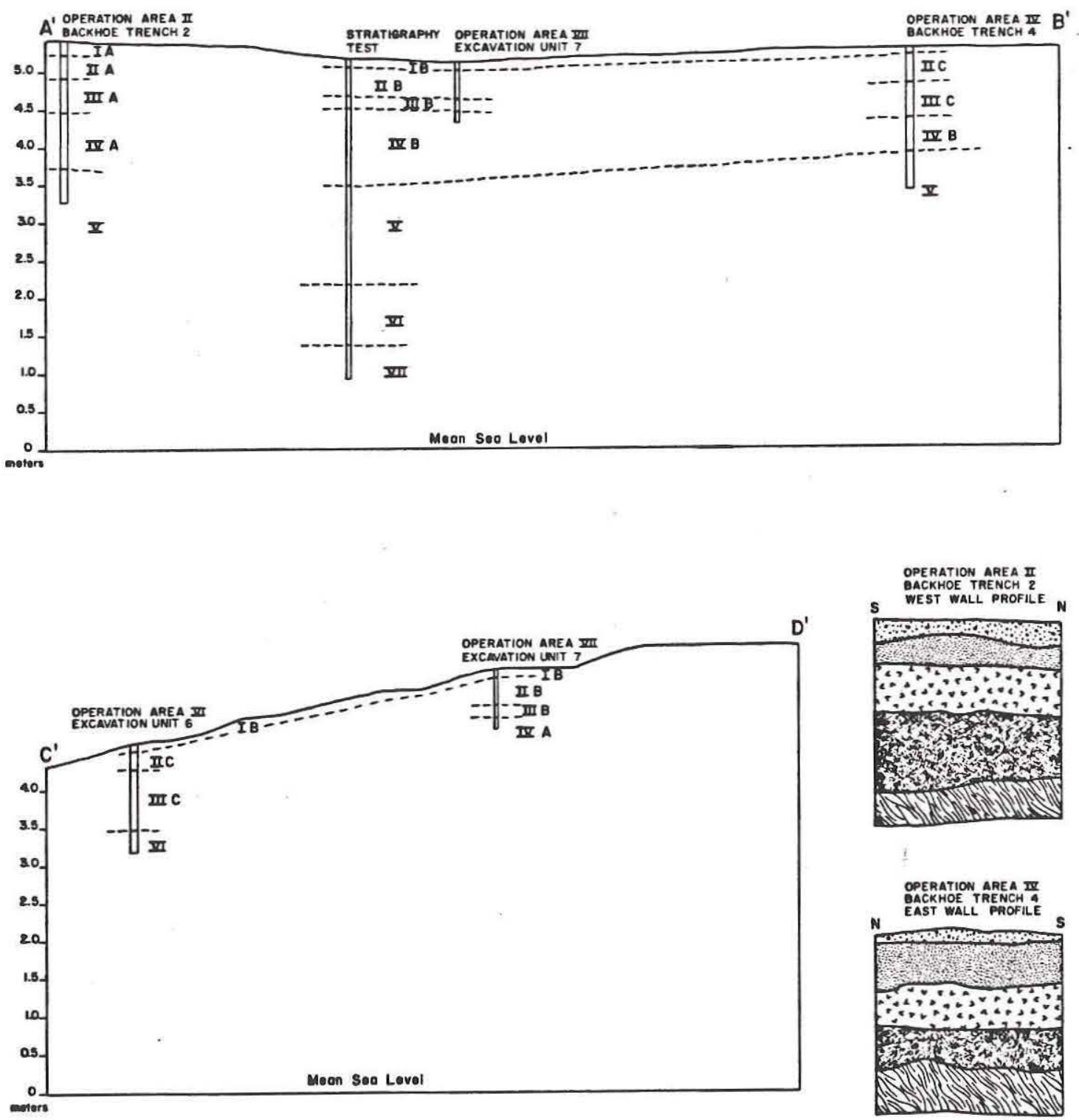

OPERATION AREA II

WEST WALL PROFILE N

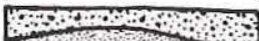

0 ron

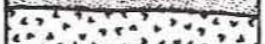

$\because 343, \ldots, ?$
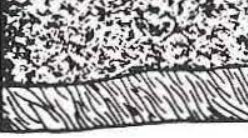

OPERATION AREA TI

BACKHOE TRENCH A

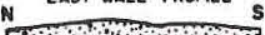

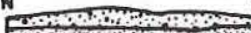

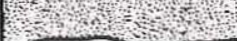

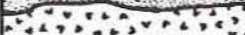
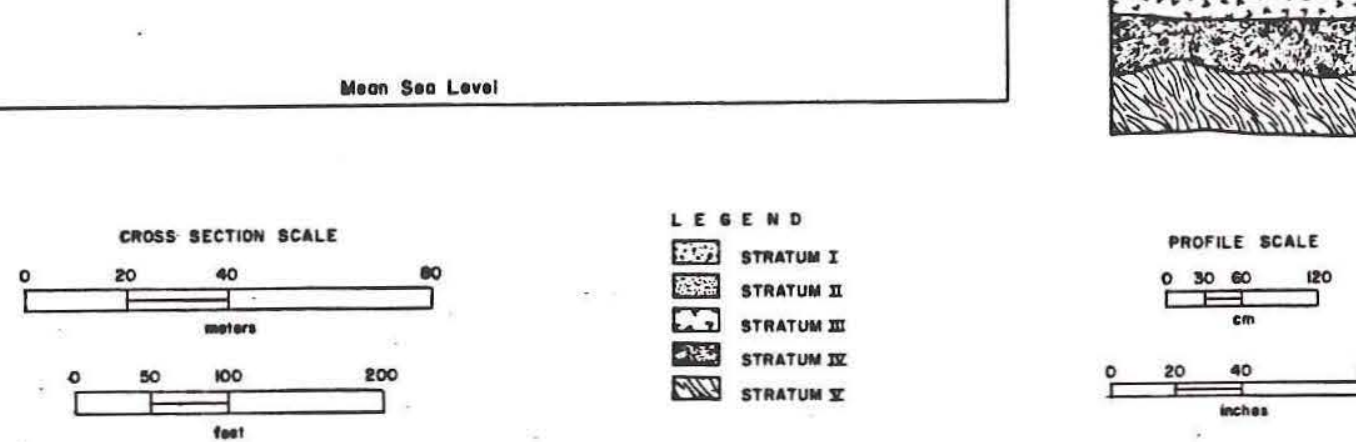

LEGEND

STRATUM I

PROFILE SCALE

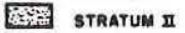

E. STRATUM II

AR: STRATUM IX

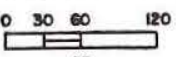

SIV STRATUM $x$

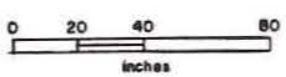


texture is characterized as a clay loam, and IVA differentiated because of the presence of infrequent, white, calcium carbonate concretions. Stratum IV is discontinuous at an unknown point between operation Areas VI and VII.

\section{Stratum V}

Stratum $V$ is composed of light yellowish-brown (1OYR 6/4) to very pale brown (10YR 7/4) soil. It exhibits an increase in moisture and a decrease in compactness from the overlying strata. The $\mathrm{pH}$ is slightly basic (7.8) throughout. The stratum appears to be approximately 130 centimeters thick. The texture is a silty clay loam which contains an abundance of white calcium carbonate concretions. Stratum $V$ is discontinuous at an unknown point between operation Areas VI and VII.

\section{Stratum VI}

Stratum VI was observed only in the stratigraphic Test and is below the water table. It is a very compact gray sand that contains pebble-sized greenish-gray sandy concretions.

\section{EXCAVATION RESULTS}

As expected, a paucity of artifacts were collected during the investigations at site 41WY71. The categories and frequencies of cultural materials include a core tool, three pieces of lithic chipping debris, nine bone fragments, one marine shell, seventy-nine burned clay lumps, and a small quantity of charcoal flecks (see Artifact Analysis, Appendix I). No diagnostic tools or features (such as hearths or human burials) were encountered during the excavations. The sparse quantity of materials and the lack of diagnostic or datable materials precludes any determination of activity areas or specific chronological association.

Excavation Unit 4 in Operation Area IV produced the bulk of recovered materials. Excavation units at operation Areas I and VII and Excavation Unit 8 contained only minimal numbers of artifacts. No cultural materials were recovered in the excavation units at operation Areas II and II during any excavations utilizing the backhoe. The majority of artifacts collected are associated with stratum II and the remainder with stratum III. There appears to be no substantial difference in the categories of artifacts collected from the two strata. 


\section{DESCRIPTION}

Site 41 WY 72 is situated on the front slope of a
natural levee TEXTT $_{\text {REDACTED }}$

The floral cover is dominated by thorny brush and shrubs ranging from 1.0 to 1.5 meters high. The brush is recent regrowth which has emerged following clearing operations that were designed to improve the pasture. small open areas of bermudagrass occur sporadically within the brush. A dense stand of mesquite trees and brush line either side of the ranch road and forms a plant species barrier along the edge of the relict channel. Only salt-tolerant grasses cover the floor of the channel scar and the northern depression.

\section{INVESTIGATION DATA}

Operation Areas

Table 3 contains a summary of the activities accomplished within the nine operation Areas of site 41WY72. Included is information concerning (1) the specific numerical designation of each excavation, (2) the types of excavations accomplished in each area (Backhoe Trenches and Test Units), (3) the dimensions of each excavation, (4) the number of profiles drawn, and (5) the locations of the wall profiles. Six backhoe trenches and eight test units were excavated at site $41 \mathrm{WY} 72$.

The backhoe trenches were excavated in operation Areas I-VI. Trenches 1, 2, 4 and 5 are oriented approximately north-south and Trenches 3 and 6 are oriented approximately east-west. Each trench is approximately 10 meters long and ranges in depth from 1.54 meters (Trench 1) to 2.24 meters (Trench 3) below ground surface. Two 2-meter-wide scale profile drawings each were made of Trench 1 and Trench 2. For the remainder of the trenches, only one profile was drawn (Trenches $3-6$ ). 


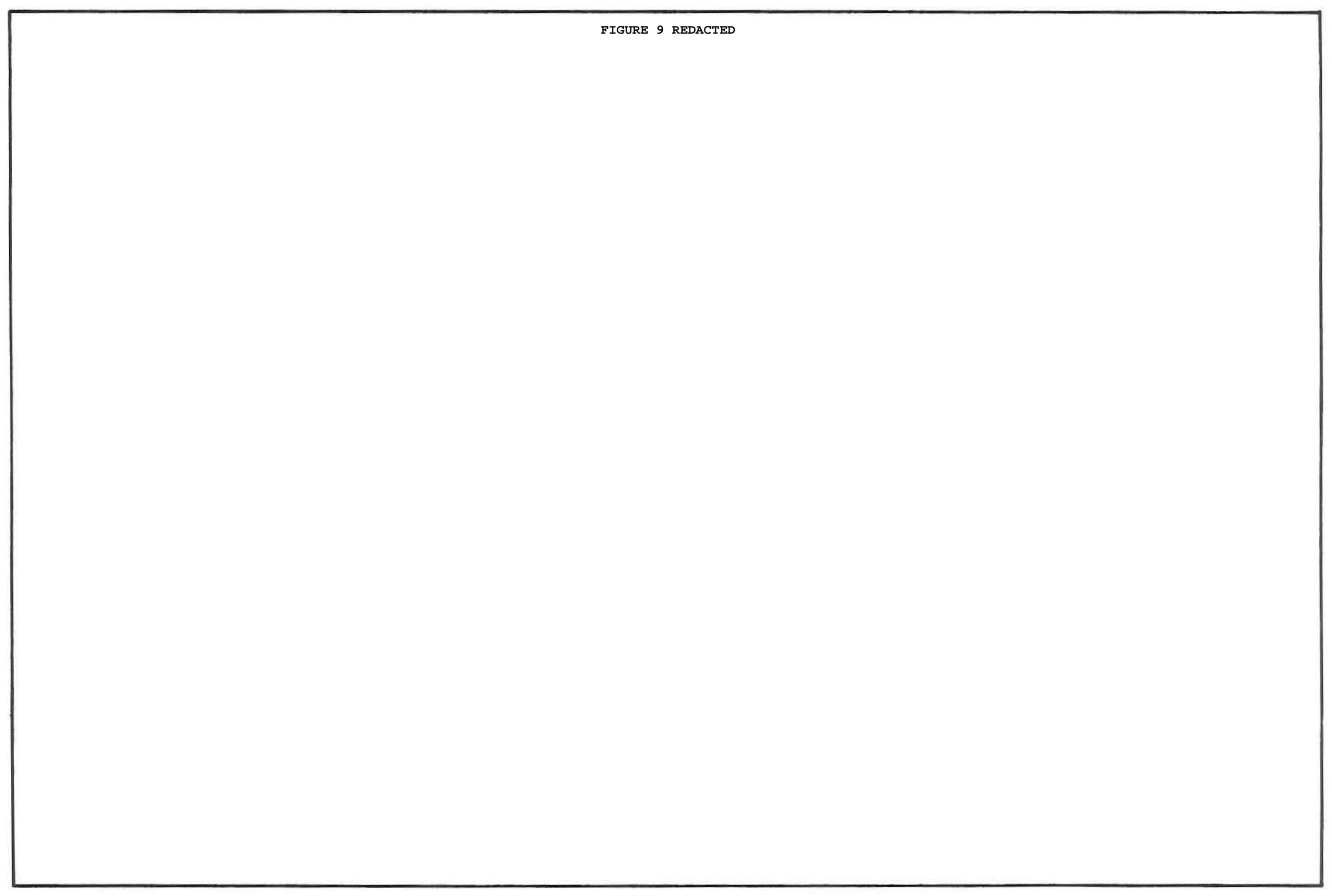


TABLE 3

41WY72: OPERATION AREA ACTIVITY DESCRIPTION

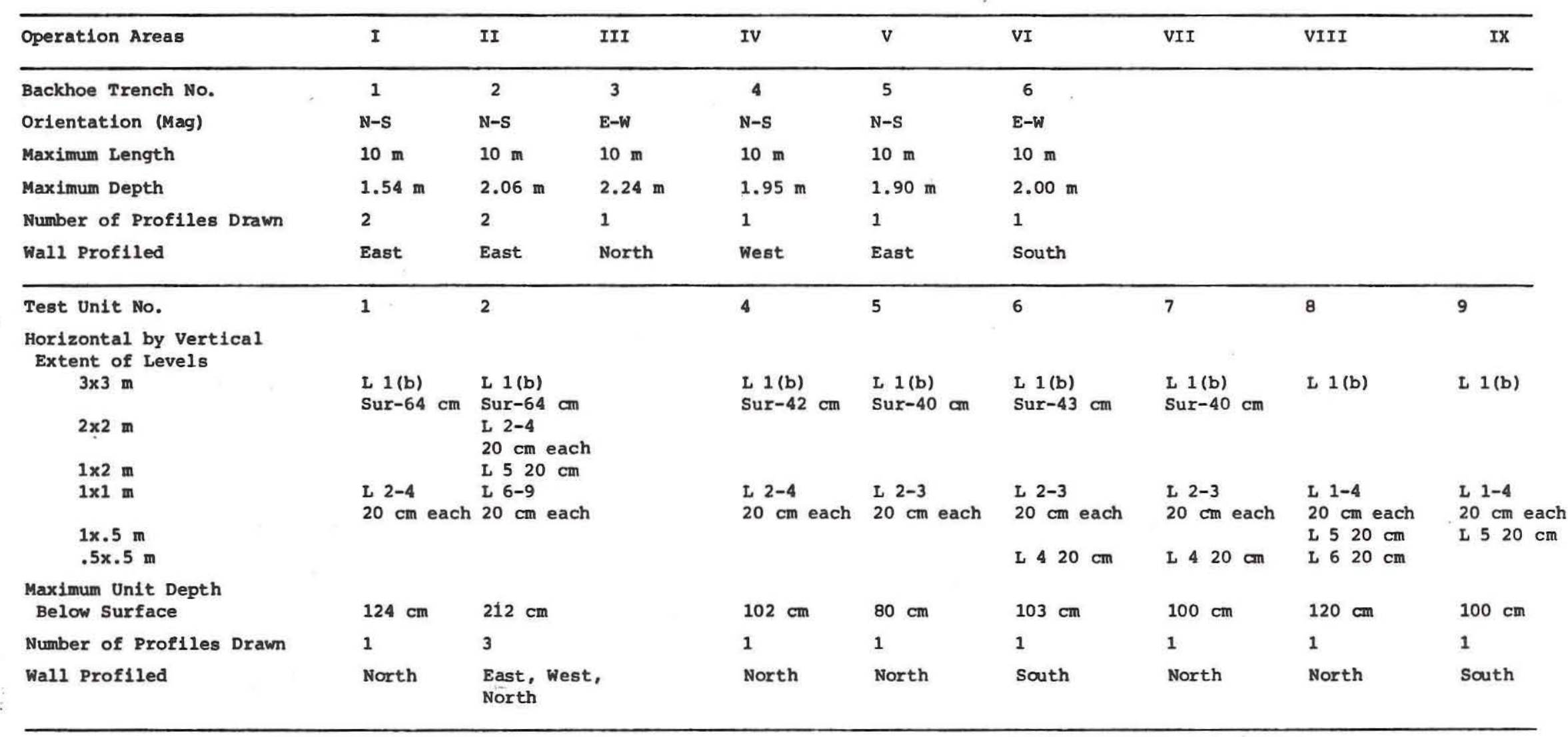

(b) = level excavated by backhoe; $\mathrm{m}=$ meters; $\mathrm{cm}=$ centimeters; $\mathrm{L}=$ arbitrary level. 
The test units were excavated in operation Areas I, I and IV-IX. There were no test units excavated in Operation Area III. Test Units 1, 2 and 4-6 were associated with Trenches 1,2 and 4-6. Test Unit 7 was excavated near the center of the investigation area. Test Units 8 and 9 were placed near the southern extent of the site within the planned realignment of the North Ditch. Specific dimensions of each level removed from the test units is provided in Table 3 and includes a designation of those levels that were excavated with the backhoe (b). The levels excavated by the backhoe represent the arbitrary removal of sterile overburden. They range in depth from 0-40 centimeters (Units 5 and 7 ) to 0-64 centimeters (Units 1 and 2). The lower levels were excavated in 20-centimeter arbitrary increments. One wall of Excavation Units 1 and 4-9 and three walls of Unit 2 were drawn to scale.

\section{$\underline{\text { Stratigraphy }}$}

The five strata recognized at 41 WY72 are described in this section. The descriptions are presented in the order of encounter; that is, the surface stratum is described first and the lowest stratum last. Color notations refer to standard Munsell color designations (Munsell Color Co. 1975). Figure 10 indicates generalized cross sections and selected profiles from 41 WY 72 .

\section{Stratum I}

Stratum I ranges in color from a very dark brown (1OYR 4/2) to a dark grayish-brown (10YR 4/2) in IA and a very dark gray (IOYR 3/1) to a dark gray (10YR 4/1) in IB and IC. The soil is dry and compact, and the stratum averages approximately 40 centimeters thick. A mat of grass, shrub and brush roots are contained near the surface, and rotted tree roots are present. The pH is slightly basic (7.6-8.0) throughout. Textural variation ranges from a fine sandy loam (IA) to a sandy clay (IB) to a silty clay loam (IC).

\section{Stratum II}

The following color variations were observed in Stratum II: IIA, brown (10YR $4 / 3$ to $10 Y R 5 / 3$ ); IIB and IIC, very dark grayish-brown (10YR 3/2) to grayish-brown (10YR 5/2); IID, dark grayish-brown (1OYR 4/2) to grayish-brown (1OYR 5/2) with yellowish-brown (10YR 5/4) mottling; and IIE, very dark gray (1OYR $3 / 1)$ to dark gray (10YR 4/1). The soil is dry and compact, but becomes slightly more moist near the bottom. The average thickness of the stratum is approximately 37 centimeters. Rotting taproots and root stains were observed. The $\mathrm{pH}$ is basic (8.0-8.2) throughout. 


\section{CULTURAL RESOURCE ASSESSMENT \\ 41 WY 72}

CROSS SECTIONS \& SELECTED PROFILES
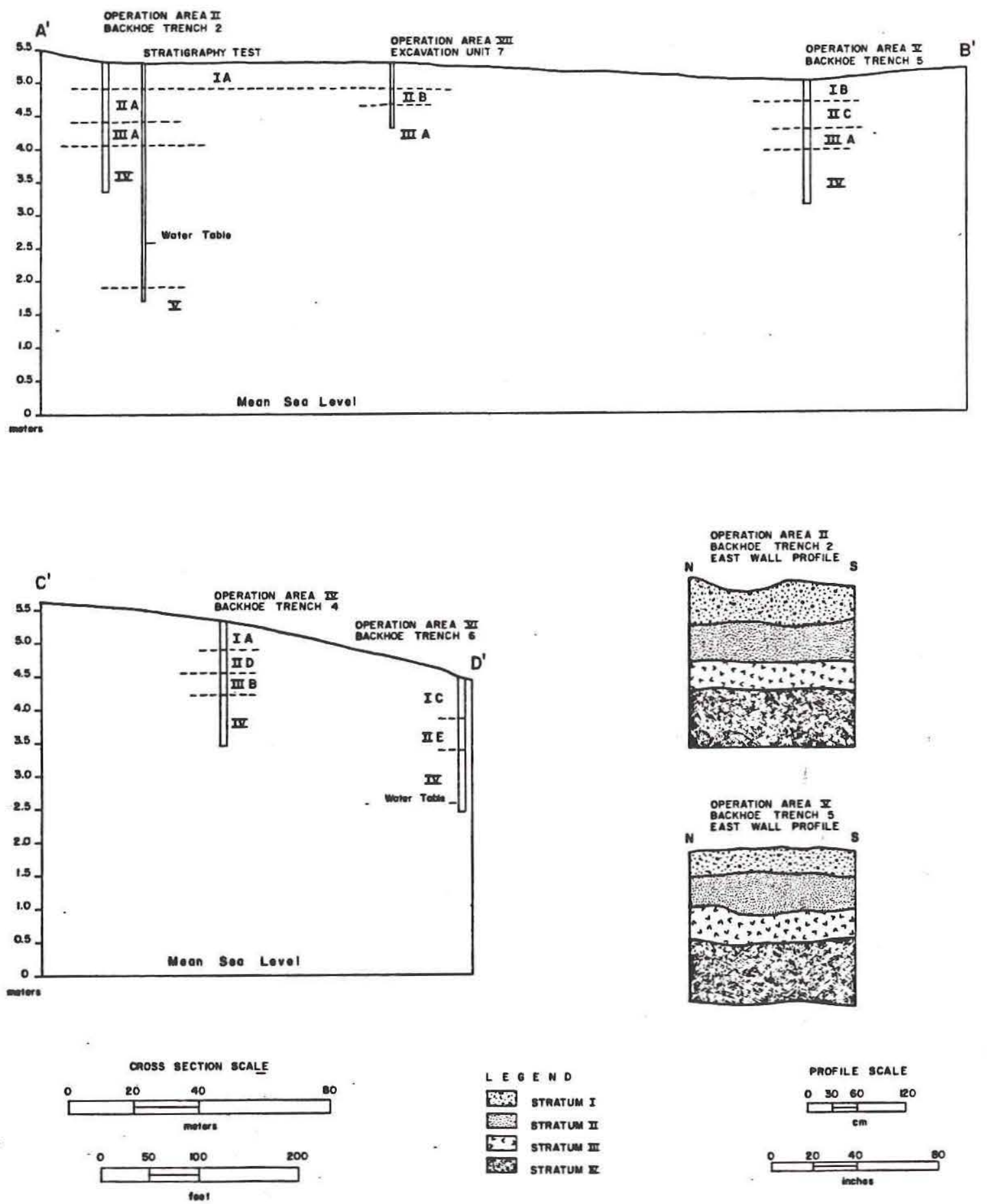

PROFILE SCALE

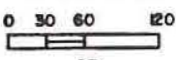

en

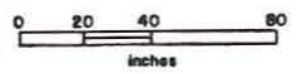

PAAIRIISEP 
Texture varies from a sandy clay loam (IIA) to a clay loam (IIB) to a sandy clay (IIC and IID) to a silty clay loam (IIE).

\section{Stratum III}

Stratum III coloration ranges from dark yellowishbrown (10YR 4/6) to yellowish-brown (10YR 5/6) in IIIA, and brown (1OYR $4 / 3$ to lOYR $5 / 3$ ) in IIIB. The soil is moist and compact, and the stratum averages approximately 32 centimeters thick. Root staining was observed. The $\mathrm{pH}$ is basic (8.0-8.2) throughout. Textural variation includes a clay loam (IIIA) and a sandy clay loam (IIIB). Stratum III is discontinuous at an unknown point between Operation Areas IV and VI.

\section{Stratum IV}

Stratum IV is composed of yellowish-brown (10YR $5 / 4$ ) to light yellowish-brown (10YR 6/4) moist soil that is less compact than stratum III. Root stains were observed in the upper portion of the stratum, and the water table was encountered in the lower half. The pH is basic (8.2) throughout. The average thickness of the stratum is approximately 215 centimeters. The texture is a clay loam containing an abundance of white calcium carbonate concretions.

\section{Stratum V}

Stratum $V$ was observed only in the stratigraphic test which extended below the water table. It is a very compact gray sand.

\section{EXCAVATION RESULTS}

The following categories and frequencies of cultural materials were collected during the excavations at site 41WY72: 1 handstone or mano, 2 ceramic sherds, 37 pieces of lithic chipping debris (including 7 pieces of green glass or obsidian), 145 bone fragments, 231 burned clay lumps, and a small quantity of charcoal flecks (see Artifact Analysis, Appendix I). No features (such as hearths or human burials) were located during the course of excavations.

Artifacts were recovered from all excavation units at 41 WY72. Test Unit 8 produced only one decorticate chert chip and Unit 9 produced six burned clay lumps. No cultural debris was found in the backhoe excavations. All cultural materials were associated with strata II and III. The artifacts in stratum II did not extend as far north as Operation Area $V$ nor as far west as Unit 8. 
Artifacts in Stratum III were encountered in all operation Areas and Test Units.

The materials collected from stratum II in Unit 2 are composed mostly of bone fragments, burned clay lumps and a small sample of lithic debitage. In contrast, the artifacts recovered from stratum II in Unit 6 are composed mostly of lithic chipping debris with only minimal numbers of bone fragments, burned clay and charcoal flecks. Small amounts of lithic debitage and burned clay lumps are characteristic of the materials collected from other excavation units.

Artifacts associated with stratum III do not form as clear a pattern. However, Test Unit 2 materials from Stratum III do appear to differ somewhat from those in Unit 1. Ceramics, bone fragments, burned clay lumps, charcoal flecks and one decorticate chip were found in Unit 1. This contrasts with unit 2 where four pieces of lithic chipping debris and two burned clay lumps were found.

\section{INTERPRETATIONS AND CONCLUSIONS}

The environmental setting of archeological sites 41WY71 and 41WY72 appears to represent a determining factor in the selection of aboriginal campsites. The relict channel and associated eolian depression is presumed to have provided a source of potable water which also supported vegetation and wildife resources. These resources could have at least partially filled the subsistence needs of aboriginal peoples. The elevated natural levees afforded protection from flooding. Further, the abundant food resources of the Laguna Madre estuary are easily accessible from the sites.

The cultural materials which were recovered strongly indicate a hunting and gathering economy at both sites. A core tool (4IWY71) and a handstone (41WY72) are the only identifiable implements collected. The lithic debitage collected represents the final stages of lithic reduction associated with tool manufacture or the refashioning and resharpening of existing and broken tools. Materials recovered include chert, rhyolite, quartzite and either green glass or obsidian. The material type with the highest frequency of occurrence is chert; this indicates that chert may have been the most easily obtainable lithic resource. Importantly, no known chert or other lithic sources exist within 128.8 kilometers of sites $41 W Y 71$ and $41 W Y 72$. Either travel and/or trade were necessary to obtain these items. The absence of primary and secondary flake 
debitage indicates that the initial stages of core reduction were carried out elsewhere; this was most probably done at a quarry.

Two ceramic sherds were found at 41 WY72. These are so small that the typological affiliations and vessel forms cannot be identified. While there is no question that the local peoples either manufactured ceramic items or obtained vessels through trade, the form and function of these wares remains undetermined. The sherds are similar to four specimens from nearby 41 wy 50 and a single sherd from 41 WY9. Seven sherds from three sites is rather sparse, but they provide an implication of a local pattern both in the manufacturing techniques (all are sandy pastel and in the infrequency of occurrence. There are three probable explanations for the scarcity of ceramics. First, the highly mobile nature of the resident aboriginal groups may have precluded widespread adoption of ceramics as a storage or cooking medium. Or, second, the ceramics represent trade items which were highly prized and particular care was taken to avoid breakage of the vessels. The third, and most likely, explanation combines the first two; that is, the vessels were probably obtained through trade, but the need for group mobility discouraged the accumulation of large quantities of the relatively fragile and difficult to transport ceramics.

The single marine shell fragment recovered from 41 WY71 supports the suggestion that the Laguna Madre estuary system was included within the normal exploitation range of these groups. Additional faunal remains from both sites are dominated by turtles, small mammals and deer-sized mammals. All of these support the basic concept of a hunting and gathering adaptation.

Burned clay lumps and isolated areas of charcoal flecks were also noted. While no hearth features were encountered, the evidence points to cooking and heating activities traditionally associated with hearth-area activities.

Both sites contain stratified cultural deposits. The artifacts were found in strata II and III in both sites. The horizontal extent of the sites could not be precisely determined. It is clear, though, that the density of artifacts and debris decreases toward the south at both 41 WY71 and 41 WY 72 .

The primary difference in the two sites is the relative frequency of artifacts. The amount of cultural materials recovered from $41 \mathrm{WY} 71$ is noticeably less than that found at 41 WY72. The materials from 41 WY72 strongly suggest that isolatable activity areas are present 
and that they can tentatively be segregated into chipping stations and areas associated with hearth activities. These differences support an interpretation that 41 WY71 represents a temporary campsite and 41 WY72 represents a semipermanent campsite.

Specific cultural affiliations cannot be determined from the artifacts recovered. No precisely dated materials were collected. However, the presence of ceramic sherds at 41 WY 72 suggests a late prehistoric occupation. Further, the presence of glass or obsidian at 41 WY72 may be an indication of age. That is, if the material is green glass then the occupation occurred after the spanish began settlement in the region. If it is obsidian, then the occupation probably occurred in late prehistoric times, possibly just before the spanish invasion of Mesoamerica. The stratigraphic similarities of the two sites suggest that they are similar in age although the material associations are insufficient to make a final determination.

\section{ASSESSMENTS AND RECOMMENDATIONS}

The investigations at site 41 WY71 indicate that stratified low-density cultural deposits are present. The limited quantity of artifacts suggestive of a temporary campsite occurred between the top of stratum II and the bottom of stratum III. The lack of cultural features, human burials, diagnostic tools, and datable materials indicates that site 41 WY71 has a low information yield potential. No additional archeological investigations are warranted at site 41WY71. The site is not considered eligible for nomination to the National Register of Historic Places.

Site 41WY72 is characterized as a semipermanent campsite that contains stratified and relatively dense cultural materials. Patterns of artifact distributions suggest the existence of isolatable activity areas. The presence of ceramic sherds and green glass or obsidian debitage indicates that the site is late prehistoric in age. The total sample of cultural debris recovered typifies a hunter/gatherer tradition. The vertical distribution of artifacts is limited to stratum II and stratum III. Site $41 W Y 72$ is assessed to contain a high information yield potential. The site is believed to be worthy of nomination to the National Register of Historic Places. 
Major portions of sites 41 WY71 and 41 WY72 appear to lie in the direct path of the North Ditch as originally proposed. A realignment designed to avoid major conflicts with the cultural resources was adopted prior to the completion of this report (Fig. 11). The realignment shifts the channel to the south of the two sites. Test excavations conducted within the modified alignment indicate that the main concentrations of sites 41 WY71 and 41 WY 72 will not be affected by construction of the North Ditch.

However, there is a possibjlity that additional significant cultural materials may be encountered during construction. Monitoring is therefore recommended during construction activities in the vicinity of 41 WY71 and 41 WY72. It should be noted that difficulties were encountered during the current investigations in terms of the visibility of artifacts and debris during machine-aided excavations.

If potentially significant sites are identified during monitoring, then the general procedures contained in the original survey report (Day, Laurens-Day and Prewitt 1981) should be implemented. 

Baxter, Edward P. and Kay L. Killen

1976 A Study of the Palo Alto Battleground, Cameron County, Texas. Texas A\&M University, Anthropology Laboratory Report 33 .

Beardsley, R. K., P. Holder, A. D. Krieger, B. J. Meggers, J. B. Rinaldo and P. Kutschie

1956 Functional and Evolutionary Implications of Community Patterning. In: Robert Wauchope, editor, Seminars in Archaeology: 1955: 129157. Memoirs of the Society for American Archaeology No. 11 .

Blair, W. Frank

1950 The Biotic Provinces of Texas. Texas Journal of Science 2(1): 93-117.

Boggs, Wayne

n.d. Brazos Santiago Depot Archeological District (41CF4), Cameron County, Texas; 1980 Investigations. Notes on file at the office of the State Archeologist, Texas Historical Commission, Austin.

Campbell, T. N.

1975 The Payaya Indians of Southern Texas. Southern Texas Archaeological Association Special Publication 1. San Antonio.

1977 Ethnic Identities of Extinct Coahuiltecan Populations: Case of the Juacana Indians. The Pearce-Sellard Series 26. Texas Memorial Museum, Austin.

Collins, Michael B., Thomas R. Hester and Tom S. Ellezy

n.d. Excavations at Resaca de la Palma, a Mexican War Site (41CF3), Cameron County, Texas. Notes on file at the Texas Archeological Research Laboratory, The University of Texas at Austin.

Corbin, James E. and Curtis D. Tunnell

n.d. $\quad 1967$ Archeological Investigations at Brazos

Santiago Depot, 41CF4, Cameron County, Texas. Notes on file at the office of the state Archeologist, Texas Historical Commission, Austin. 
Day, D. William, Jane Laurens-Day and Elton R. Prewitt 1981 Cultural Resources Surveys and Assessments in Portions of Hidalgo and Willacy Counties, Texas. Prewitt and Associates, Inc. Reports of Investigations 15 . Austin.

Goddard, Ives

1979 The Languages of South Texas and the Lower Rio Grande. In: Lyle Campbell and Marianne Mithun, editors, The Languages of Native America: Historical and Comparative Assessment: 335-389. The University of Texas Press, Austin and London.

Hester, Thomas R.

1981 Tradition and Diversity among the Prehistoric Hunters and Gatherers of Southern Texas. Plains Anthropologist 26-92: 119-126.

Inglis, Jack M.

1964 A History of Vegetation on the Rio Grande Plain. Texas Parks and Wildlife Department Bulletin 45 .

Jackson, A. T. 1940 Tubular Pipes and Other Tubes in Texas. Bulletin of the Texas Archeological and Paleontological society 12:99-137.

MacNeish, Richard S. 1947 A Preliminary Report on Coastal Tamaulipas. American Antiquity 13(1): 1-15.

1958 Preliminary Archeological Investigations in Sierra de Tamaulipas, Mexico. Transactions of the American Philosophical Society 48:6.

Mallouf, Robert J., Barbara J. Baskin and Kay L. Killen 1977 A Predictive Assessment of Cultural Resources in Hidalgo and Willacy Counties, Texas. Texas Historical Commission, Office of the State Archeologist Survey Report 23 .

Munsell Color Co.

1975 Munsell Soil Color Charts. Macbeth Division of Kollmorgen Corporation, Baltimore.

Newcomb, W. W. Jr.

1961 The Indians of Texas. University of Texas Press, Austin. 
Nunley, J. Parker

1971

Sociocultural Units of the Southwestern Texas Archaic: An Analytical Approach. Unpublished Ph.D. dissertation, Southern Methodist University, University Microfilms, Ann Arbor.

Nunley, J. Parker and Thomas R. Hester

1975

An Assessment of Archaeological Resources in Portions of Starr County, Texas. The University of Texas at San Antonio, Center for Archaeological Research Archaeological Survey Report 7 .

Ruecking, F. A., Jr.

1955 The Coahuiltecan Indians of Southern Texas and Northern Mexico. Unpublished M.A. thesis, The University of Texas at Austin.

Saldivar, Gabriel

1943 Los Indios de Tamaulipas. Instituto Panamericano de Geografia y Historia, Publication 70 . Mexico, D.F.

Soil Conservation service

ms. Soil Survey of Willacy County. Manuscript in preparation.

Suhm, Dee Ann, Alex D. Krieger and Edward B. Jelks 1954 An Introductory Handbook of Texas Archeology. Bulletin of the Texas Archeological Society 25 .

U.S. Army Engineer District, Galveston

1979 Draft Environmental Impact statement. By Hidalgo County Drainage District No. 1 for tlood control and major drainage improvements in Willacy and Hidalgo counties, Texas.

Victor, sally s.

1981 Appendix I: Historical Background. In: D. William Day, Jane Laurens-Day and Elton R. Prewitt, Prewitt and Associates, Inc. Reports of Investigations $\overline{15}: \overline{93-148 .}$ Austin. 
APPENDIX I: Artifact Analysis

D. William Day

and

Jane Laurens-Day 


\section{INTRODUCTION}

Excavations yielded 93 specimens from site 41 WY71 and 506 specimens from 41WY72. These materials indicate aboriginal use of the area. With one exception, a handstone from 41 WY 72 , the cultural debris was retrieved from the controlled hand excavations rather than from the machine excavations.

Six major categories of artifacts and debris are defined by utilitarian or physical characteristics. The categories are (1) ground, pecked and battered stone; (2) knapped stone; (3) ceramics; (4) faunal remains; (5) marine shell; and (6) burned clay lumps. Subcategories delineate observed variations among the materials of each category. Information is also provided for charcoal flecks and terrestrial snail shells due to their possible association with cultural debris.

Each artifact category is described separately. The descriptions include the types of material, the dimensions of the specimens, and the provenience. The following abbreviations are used for the metric data: I for length, $W$ for width, $T$ for thickness, and $\mathrm{mm}$ for millimeters. Specific provenience data for all materials recovered is provided in Tables 7 and 8 .

The terminology used in this analysis is adapted from the previous works by Mallouf, Baskin and Killen (1977) and Day, Laurens-Day and Prewitt (1981). The intent is to provide a consistent means of analysis to facilitate comparative intraregional studies.

\section{GROUND, PECKED AND BATTERED STONES}

A single item is included in this category which consists of artifacts that have been shaped either through intentional fashioning or through use.

\section{GROUND STONE}

Handstone (1 spec., Fig. 12b)

Description: This specimen is a fragment with ground and natural smooth surfaces except where broken. A limited amount of incipient pitting, possibly from light use as a hammer, is noticeable on the intact surfaces.

Material: Fine-grained quartzite 
Figure 12
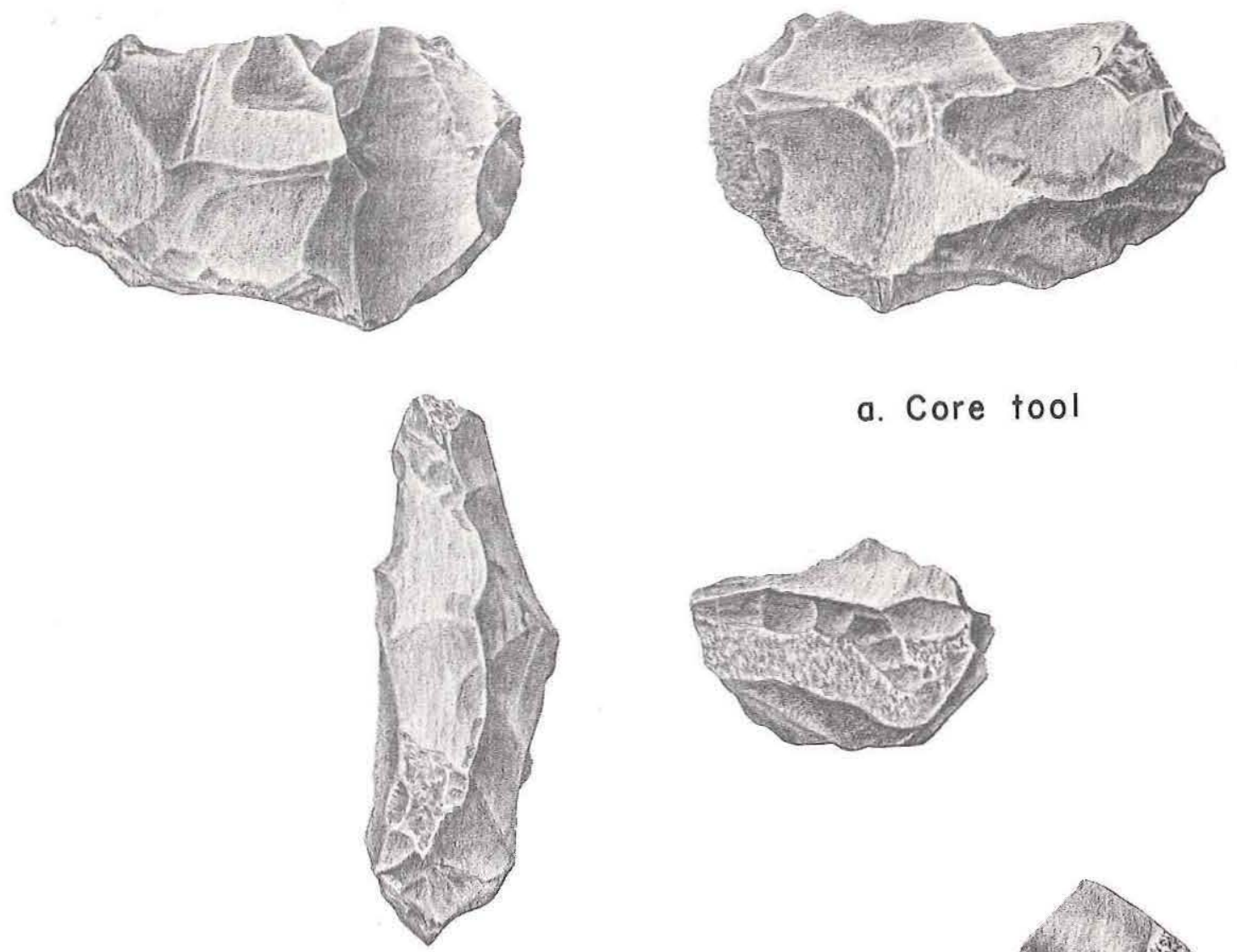

a. Core tool

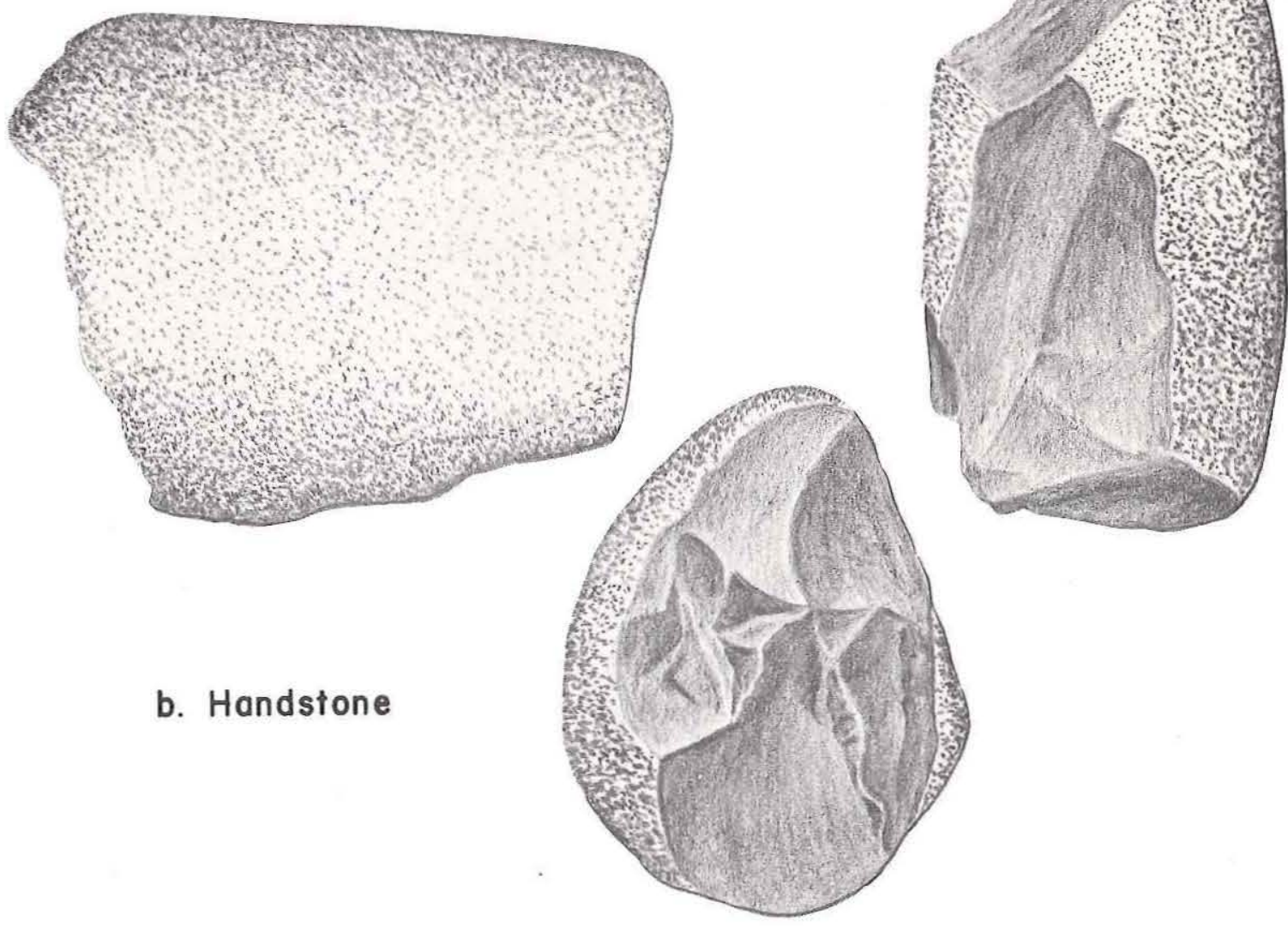




\title{
Dimensions: $85 \mathrm{~mm} \mathrm{L;} 55 \mathrm{~mm} \mathrm{~W} ; 51 \mathrm{~mm} \mathrm{~T}$. \\ Provenience: Site $41 W Y 72$, Operation Area I
}

\author{
KNAPPED STONE
}

The knapped stone category includes both implements and debitage. Cores are defined as nodules of stone that serve as parent pieces from which flakes are removed through direct and/or indirect percussion techniques. Samples of cores previously collected from sites in Hidalgo and Willacy counties suggests both direct percussion and bipolar flake removal techniques were used in this region (Day, Laurens-Day and Prewitt 1981).

Lithic debitage is divided into two subcategories, Flakes and chips. Flakes are characterized as specimens which retain a complete or recognizable striking platform. Chips are the distal fragments of flakes which do not retain recognizable striking platforms.

Each flake was examined to determine the following characteristics: (1) percent of remaining cortex (primary, secondary or tertiary); (2) material type; (3) size range; (4) fragment or complete; (5) platform type (single facet, multiple facet or crushed); (6) surface modification; and (7) method of flake removal. Each chip was analyzed to determine (1) material type; (2) amount of cortex (corticate, partially decorticate or decorticate); and (3) surface modification.

CORES

Core tool (1 spec.; Fig. 12a)

Description: This specimen appears to be a depleted core. It is small and lacks sufficient surface area to allow for further flake removal. Less than $5 \%$ of the cortex remains. Wear is extensive on the ends but is slight along the lateral edges. The wear pattern suggests that the core has been used secondarily as a hammer.

Material: Chert

Dimensions: $60 \mathrm{~mm} \mathrm{~L} ; 36 \mathrm{~mm} \mathrm{~W} ; 20 \mathrm{~mm} \mathrm{~T}$.

Provenience: Site 41WY71, Operation Area I 
Flakes

Tertiary (20 specs.)

Description: Tertiary flakes are defined as debitage which retains whole or recognizable striking platforms and exhibits no remaining cortex. Tertiary flakes are assumed to originate during the third or final stage of core reduction or tool manufacture.

Material: 17 chert, 2 rhyolite, 1 obsidian or green glass

Size Range: 15 are $0-10 \mathrm{~mm} ; 5$ are $11-20 \mathrm{~mm}$.

Completeness: 13 fragmentary; 7 complete.

Platform Type: 13 single facet; 5 multiple facet; 2 crushed.

Surface Modification: 1 burned; 5 patinated; 1 edge-damaged.

Method of Removal: 10 soft hammer; 8 hard hammer; 2 undetermined.

Provenience: Site 41WY71, Operation Areas I and VII, 2 specimens Site $41 W Y 72$, Operation Areas I, II and IV-VII, 18 specimens.

Specific data for each tertiary flake is provided in Table 4 .

\section{Chips}

Partially Decorticate ( 1 spec.)

Description: A partially decorticate chip is a distal fragment of a flake that lacks a striking platform. The amount of cortex remaining on the dorsal face ranges from $95 \%$ to $5 \%$.

Material: Chert

Provenience: Site $41 W Y 72$, Operation Area V

Decorticate Chips (19 specs.)

Description: A decorticate chip is a distal fragment of a flake that lacks a striking platform and 
TABLE 4

SUMMARY OF TERTIARY FLAKES BY INDIVIDUAL PROVENIENCE AND CHARACTERISTICS

\begin{tabular}{|c|c|c|c|c|c|c|c|c|c|c|c|c|c|c|c|c|c|c|c|c|c|}
\hline \multirow{2}{*}{$\begin{array}{l}\text { Site } \\
\text { Operation Area }\end{array}$} & \multicolumn{2}{|c|}{41 WY 71} & \multicolumn{18}{|c|}{$41 W Y 72$} & \multirow[b]{3}{*}{$\begin{array}{l}\text { Total \# of } \\
\text { Specimens per } \\
\text { Characteristic }\end{array}$} \\
\hline & I & VII & & I & & $\mathrm{I}$ & & IV & $\mathrm{v}$ & & & & VI & & & & & & & VII & \\
\hline $\begin{array}{l}\text { Test Unit - } \\
\text { Arbitrary Level }\end{array}$ & $1-3$ & $7-3$ & $1-3$ & $1-3$ & $1-4$ & $2-3$ & $2-3$ & $4-4$ & $5-3$ & $6-2$ & $6-2$ & $6-3$ & $6-3$ & $6-3$ & $6-3$ & $6-3$ & $6-3$ & $6-3$ & $6-3$ & $7-3$ & \\
\hline $\begin{array}{l}\text { Material } \\
\text { Chert } \\
\text { Khyolite } \\
\text { Glass/Obsidian }\end{array}$ & 1 & 1 & 1 & 1 & 1 & 1 & 1 & 1 & 1 & 1 & 1 & 1 & 1 & 1 & 1 & 1 & 1 & 1 & 1 & 1 & $\begin{array}{r}17 \\
2 \\
1\end{array}$ \\
\hline $\begin{array}{l}\text { Size Range } \\
0-10 \mathrm{~mm} \\
11-20 \mathrm{~mm}\end{array}$ & 1 & 1 & 1 & 1 & 1 & 1 & 1 & 1 & 1 & 1 & 1 & 1 & 1 & 1 & 1 & 1 & 1 & 1 & 1 & 1 & $\begin{array}{r}15 \\
5\end{array}$ \\
\hline $\begin{array}{l}\text { Completeness } \\
\text { Fragment } \\
\text { Complete }\end{array}$ & 1 & 1 & 1 & 1 & 1 & 1 & 1 & 1 & 1 & 1 & 1 & 1 & 1 & 1 & 1 & 1 & 1 & 1 & 1 & 1 & $\begin{array}{r}13 \\
7\end{array}$ \\
\hline $\begin{array}{l}\text { Platform } \\
\text { Single facet } \\
\text { Multiple facet } \\
\text { Crushed }\end{array}$ & 1 & 1 & 1 & 1 & 1 & 1 & 1 & 1 & 1 & 1 & 1 & 1 & 1 & 1 & 1 & 1 & 1 & 1 & 1 & 1 & $\begin{array}{r}13 \\
5 \\
2\end{array}$ \\
\hline
\end{tabular}


TABLE 4, continued

\begin{tabular}{|c|c|c|c|c|c|c|c|c|c|c|c|c|c|c|c|c|c|c|c|c|c|}
\hline \multirow{2}{*}{ Site } & \multicolumn{2}{|c|}{41 WY71 } & \multicolumn{18}{|c|}{$41 \mathrm{WY} 72$} & \multirow[b]{3}{*}{$\begin{array}{l}\text { Total \# of } \\
\text { Specimens per } \\
\text { Characteristic }\end{array}$} \\
\hline & I & VII & & I & & II & & IV & v & & & & VI & & & & & & & VII & \\
\hline $\begin{array}{l}\text { Test Unit - } \\
\text { Arbitrary Level }\end{array}$ & $1-3$ & $7-3$ & $1-3$ & $1-3$ & $1-4$ & $2-3$ & $2-3$ & $4-4$ & $5-3$ & $6-2$ & $6-2$ & $6-3$ & $6-3$ & $6-3$ & $6-3$ & $6-3$ & $6-3$ & $6-3$ & $6-3$ & $7-3$ & \\
\hline $\begin{array}{l}\text { Surface } \\
\text { Modification } \\
\text { Burned } \\
\text { Patinated } \\
\text { Edge-damaged }\end{array}$ & & 1 & & & & & & 1 & & & 1 & 1 & 1 & 1 & & & & & 1 & & $\begin{array}{l}1 \\
5 \\
1\end{array}$ \\
\hline $\begin{array}{l}\text { Method of } \\
\text { Removal } \\
\text { Soft Hammer } \\
\text { Hard Hammer } \\
\text { Undetermined }\end{array}$ & 1 & 1 & 1 & 1 & 1 & 1 & 1 & 1 & 1 & 3 & 1 & 1 & 1 & 1 & 1 & 1 & 1 & 1 & 1 & 1 & $\begin{array}{r}10 \\
8 \\
2\end{array}$ \\
\hline $\begin{array}{l}\text { Total No. of } \\
\text { Characteristics } \\
\text { per Specimen }\end{array}$ & 5 & 6 & 5 & 5 & 5 & 5 & 5 & 6 & 5 & 5 & 6 & 6 & 6 & 6 & 5 & 5 & 5 & 5 & 6 & 5 & 107 \\
\hline
\end{tabular}


retains less than $5 \%$ cortex on the surface.

Material: 12 chert; 1 rhyolite; 6 obsidian or green glass

1 burned.

Surface Modification: 4 patinated; 2 edge-damaged;

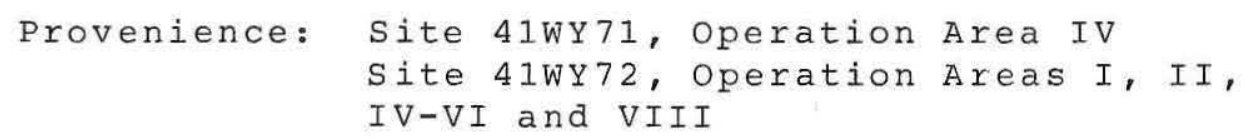

Provenience: Site 41WY71, Operation Area IV

Site 41WY72, Operation Areas I, II, IV-VI and VIII

Specific data for each partially decorticate and decorticate chip is provided in Table 5 .

\title{
CERAMICS
}

SHERDS ( 2 specs. $)$

Description: These two specimens are small sandy paste sherds. Both are badly eroded and no surface decoration could be discerned. One appears to be a rim sherd, the other is a body sherd. The body sherd has a black stain on one side which may be asphaltum.

\author{
Dimensions: Rim sherd: $16 \mathrm{~mm} \mathrm{L,} 17 \mathrm{~mm} \mathrm{W,} 5 \mathrm{~mm} \mathrm{~T}$. \\ Body Sherd: $11 \mathrm{~mm} \mathrm{L,} 10 \mathrm{~mm} \mathrm{W,} 4 \mathrm{~mm} \mathrm{T.}$ \\ Provenience: Site 41 WY 72 , Operation Area II \\ BURNED CLAY LUMPS
}

The burned clay lump specimens collected from sites 41 WY71 and $41 W Y 72$ range from $5 \mathrm{~mm}$ to $50 \mathrm{~mm}$ in maximum length. The color varies from an orange-red to a yellow-tan with occasional black stains. The burned clay lumps are easily separated from the matrix of the natural strata because they are extremely hard and have a much brighter or lighter color. Those collected from Stratum I at site $41 W y 71$ and the upper portion of Stratum I at site 41 WY72 are believed to be associated with recent brush clearing/burning activities in the area. Those specimens recovered from strata II and III at sites 41 WY71 and 41 WY72 are believed to be cultural debris which indicate the use of fire for heating and cooking activities. 
TABLE 5

SUMMARY OF LITHIC CHIPS BY INDIVIDUAL PROVENIENCE AND CHARACTERISTICS

\begin{tabular}{|c|c|c|c|c|c|c|c|c|c|c|c|c|c|c|c|c|c|c|c|c|c|}
\hline \multirow{2}{*}{$\begin{array}{l}\text { Site } \\
\text { Uperation Area }\end{array}$} & \multirow{2}{*}{\begin{tabular}{|c|}
$11 \mathrm{WY} 71$ \\
IV
\end{tabular}} & \multicolumn{19}{|c|}{41 WY 72} & \multirow[b]{3}{*}{$\begin{array}{l}\text { Total \# of } \\
\text { Specimens per } \\
\text { Characteristic }\end{array}$} \\
\hline & & & I & & II & IV & & $\mathrm{v}$ & & & & & VI & & & & & & & VIII & \\
\hline $\begin{array}{l}\text { Test Unit - } \\
\text { Arb1trary Level }\end{array}$ & $4-5$ & $1-2$ & $1-2$ & $1-3$ & $2-8$ & $4-3$ & $5-2$ & $5-3$ & $5-4$ & $6-3$ & $6-3$ & $6-3$ & $6-3$ & $6-3$ & $6-3$ & $6-3$ & $6-3$ & $6-3$ & $6-3$ & $8-5$ & \\
\hline $\begin{array}{l}\text { Material } \\
\text { Chert } \\
\text { Rhyolite } \\
\text { Glass/Obsidian }\end{array}$ & 1 & 1 & 1 & 1 & 1 & 1 & 1 & 1 & 1 & 1 & 1 & 1 & 1 & 1 & 1 & 1 & 1 & 1 & 1 & 1 & $\begin{array}{r}13 \\
1 \\
6\end{array}$ \\
\hline $\begin{array}{l}\text { Amount of Cortex } \\
\text { Partially } \\
\text { Decorticate } \\
\text { Decorticate }\end{array}$ & 1 & 1 & 1 & 1 & 1 & 1 & 1 & 1 & 1 & 1 & 1 & 1 & 1 & 1 & 1 & 1 & 1 & 1 & 1 & 1 & $\begin{array}{r}1 \\
19\end{array}$ \\
\hline $\begin{array}{l}\text { Surface } \\
\text { Modification } \\
\text { Burned } \\
\text { Patinated } \\
\text { Edge-damaged }\end{array}$ & & 1 & 1 & '. & & & 1 & & 1 & & & & & 1 & 1 & & & & & 1 & $\begin{array}{l}1 \\
4 \\
2\end{array}$ \\
\hline $\begin{array}{l}\text { Total \# of } \\
\text { Characteristics } \\
\text { per Specimen }\end{array}$ & 2 & 3 & 3 & 2 & 2 & 2 & 3 & 2 & 3 & 2 & 2 & 2 & 2 & 3 & 3 & 2 & 2 & 2 & 2 & 3 & 47 \\
\hline
\end{tabular}


The presence of charcoal flecks was observed in sites 41WY 71 and 41 WY72. The flecks are small, thin, and scattered in strata II and III. A sufficient quantity for radiocarbon assay could not be collected. It is believed that the charcoal represents evidence of hearth activities at the sites.

FAUNAL REMAINS

BONES (154 specs.)

Description: Nine specimens (one burned) were recovered from Operation Area IV at site 41 WY71 and 145 specimens ( 3 burned) from Operation Areas II, IV and VI at site 41 WY72. These faunal remains are believed to represent subsistence activities. A detailed analysis is reported in Appendix II of this report.

MARINE SHELI ( 1 spec.)

Description: This specimen is a small fragment of an unidentified marine pelecypod. No apparent intentional modification was observed although one lateral edge exhibits a small amount of rodent gnawing. The shell fragment is soft, chalky and bleached; this suggests a long period of exposure and subsequent weathering.

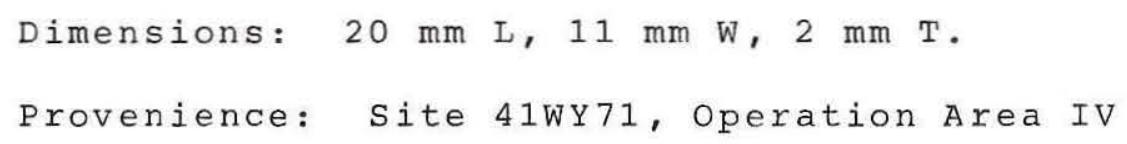

TERRESTRIAL SNAIL SHELL

Description: Identified types of terrestrial snails collected during the hand excavations include Rabdotus alternatus, Polygyra texasiana and Helicina orbiculata. Table 6 lists the identified snails by provenience. Not included are data from operation Areas VIII and IX at both sites. 
TABLE 6

IDENTIFIED TERRESTRIAL SNAIL SHELL SPECIES BY PROVENIENCE

\begin{tabular}{|c|c|c|c|c|c|c|c|c|c|c|c|c|c|c|c|c|c|c|c|c|c|c|}
\hline \multirow{2}{*}{ Site } & \multicolumn{6}{|c|}{$41 W Y 71$} & \multicolumn{15}{|c|}{$41 W Y 72$} & \\
\hline & & & IV & & & VII & & I & & & & & I & & & & & IV & . & VI & & \\
\hline $\begin{array}{l}\text { Test Unit - } \\
\text { Arbitrary Level }\end{array}$ & $4-2$ & $4-3$ & $4-4$ & $4-5$ & $4-6$ & $7-2$ & $1-2$ & $1-3$ & $1-4$ & $2-2$ & $2-3$ & $2-4$ & $2-5$ & $2-6$ & $2-7$ & $2-8$ & $2-9$ & $4-4$ & $6-2$ & $6-3$ & $6-4$ & $\begin{array}{l}\text { Total " of } \\
\text { Unit-Levels } \\
\text { Per Species }\end{array}$ \\
\hline$\frac{\text { Rabdotus }}{\text { alternatus }}$ & $\mathbf{x}$ & $x$ & $x$ & $x$ & $x$ & $\mathbf{x}$ & $x$ & $x$ & $\mathbf{x}$ & $\mathbf{x}$ & $\mathbf{x}$ & $x$ & $x$ & $x$ & $\mathbf{x}$ & $x$ & $x$ & $x$ & $\mathbf{x}$ & $\mathrm{x}$ & $1^{x}$ & 21 \\
\hline$\frac{\text { Polygyra }}{\text { texasiana }}$ & $x$ & $x$ & $\mathbf{x}$ & $x$ & & & & & & $\mathbf{x}$ & $x$ & $x$ & $x$ & $\mathbf{x}$ & $x$ & $\mathrm{x}$ & $\mathbf{x}$ & & & & & 12 \\
\hline$\frac{\text { Helicina }}{\text { orbiculata }}$ & & & & $\mathbf{x}$ & $\mathbf{x}$ & & & & & & $x$ & $x$ & & & $x$ & $x$ & $\mathbf{x}$ & & & & & 7 \\
\hline $\begin{array}{l}\text { Total \# of } \\
\text { Species per } \\
\text { Unit-Level }\end{array}$ & 2 & 2 & 2 & 3 & 2 & 1 & 1 & 1 & 1 & 2 & 3 & 3 & 2 & 2 & 3 & 3 & 3 & 1 & 1 & 1 & 1 & 40 \\
\hline
\end{tabular}

x indicates presence 
TABLE 7

DISTRIBUTION OF RECOVERED MATERIALS AT SITE $41 W Y 71$

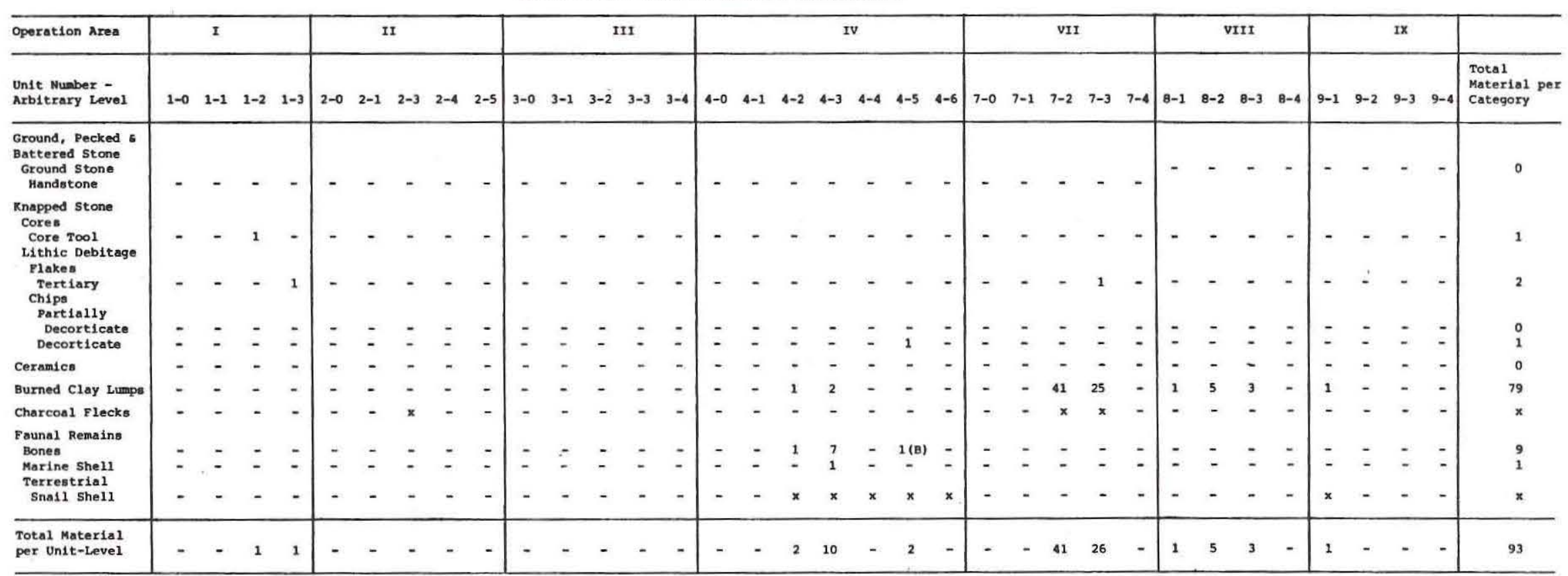

$x$ - presence in level noted but not quantified.

(B) - burned 
TABLE 8

DISTRIBUTION OF RECOVERED MATERIALS AT SITE 41 WY 72

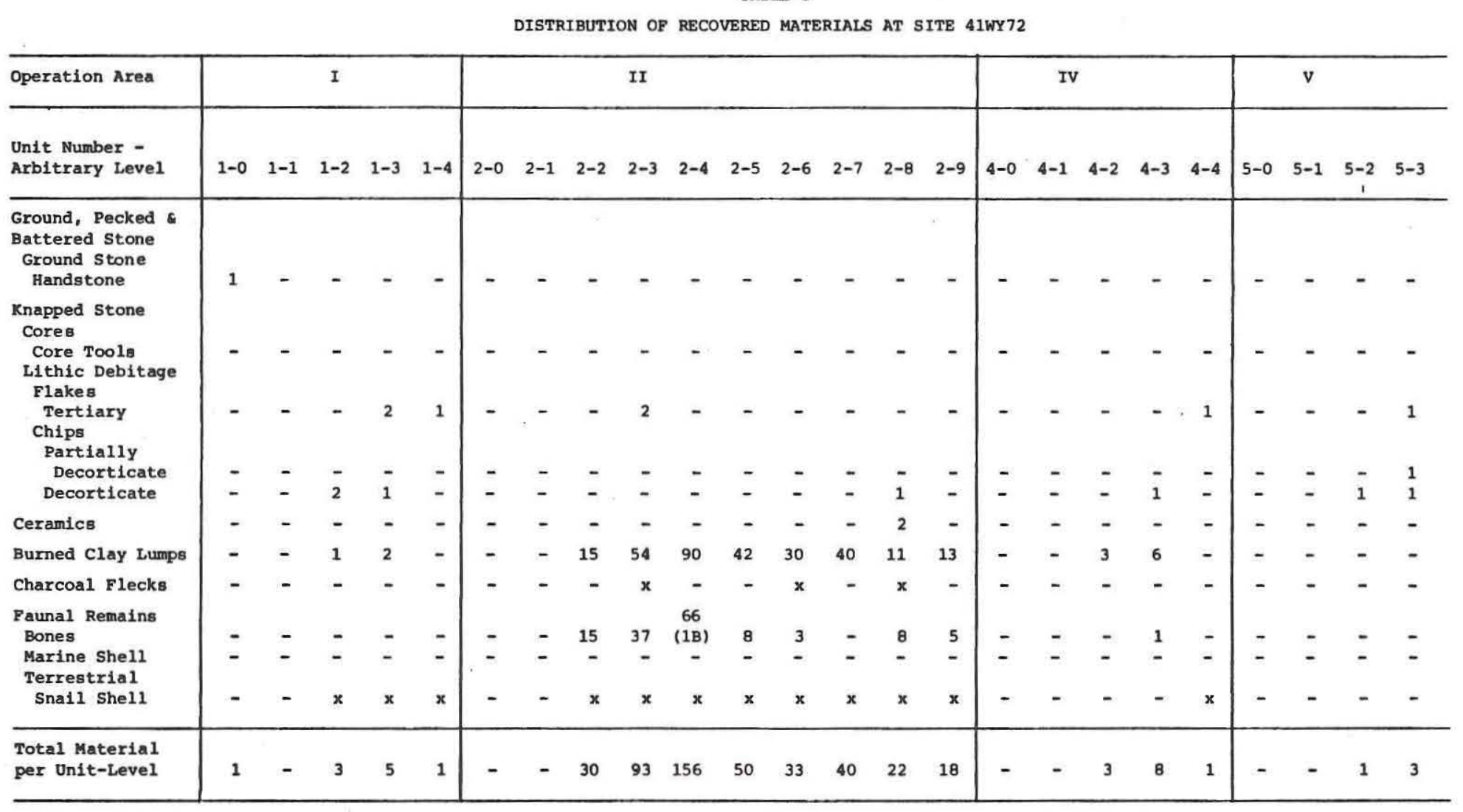

$x=$ presence in level noted but not quantified.

(B) = burned 


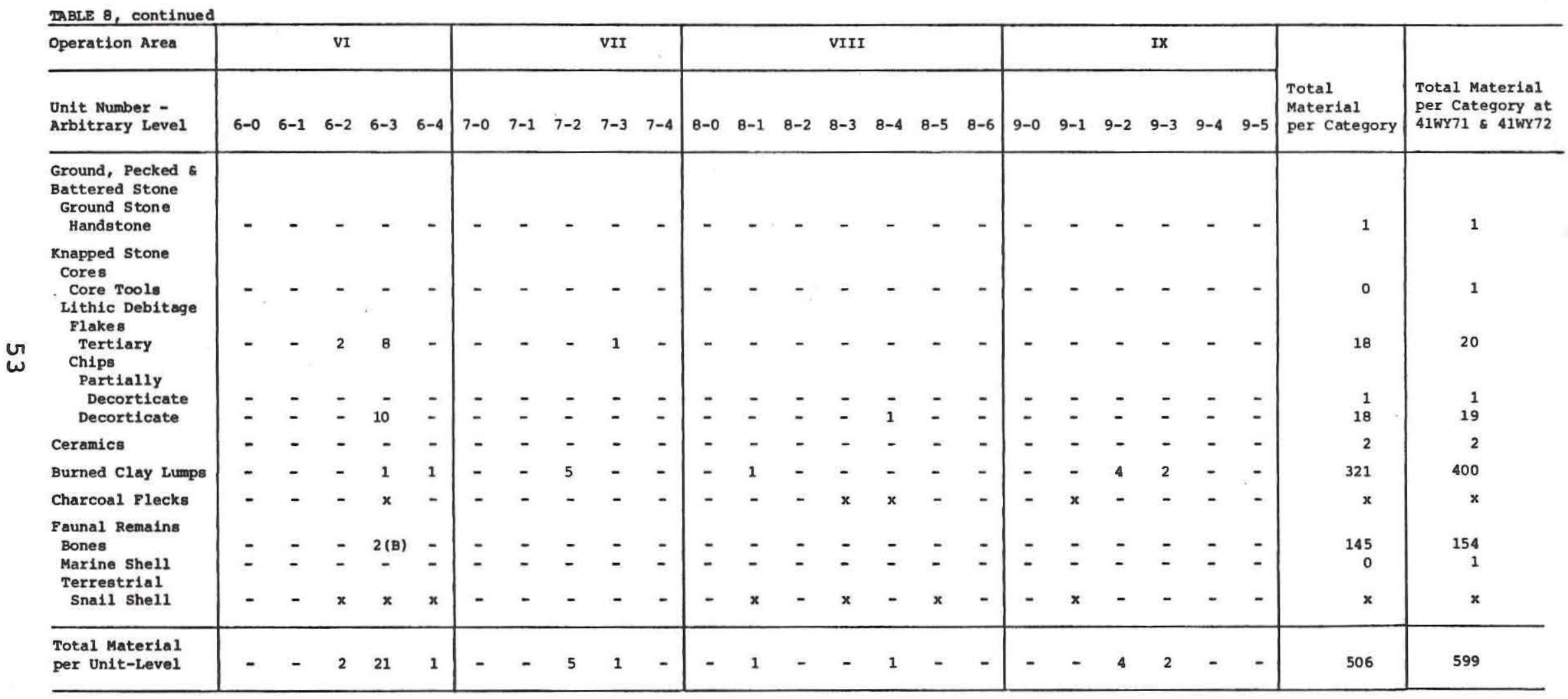


The artifacts recovered from sites 41 WY71 and 41 WY72 are summarized in Table 9. Included are the numbers and percentages of the artifacts recovered from the excavations at either site. Burned clay lumps comprise the largest percentage of artifacts recovered at both sites; 84.95 percent at 41 WY71 and 63.44 percent at 41 WY72. Faunal remains represent the next largest category with 9.7 percent at 41 WY71 and 28.65 percent at 41WY72. Knapped stone, which includes cores and lithic debitage, accounts for 4.29 percent at 41 WY 71 and 7.31 percent at 41WY72. Marine shell, which is present only at 41 WY71, accounts for 1.07 percent. Ground/pecked/ battered stone and ceramics present only at 41 WY72 account for 0.2 percent and 0.4 percent respectively.

\begin{tabular}{|c|c|c|c|c|}
\hline \multirow[b]{3}{*}{ Category } & \multicolumn{2}{|c|}{ TABLE 9} & & \\
\hline & \multicolumn{2}{|c|}{ \# of specimens } & \multicolumn{2}{|c|}{ Percent } \\
\hline & 41 WY 71 & $41 W Y 72$ & $\overline{41 W Y 71}$ & $41 W Y 72$ \\
\hline $\begin{array}{l}\text { Ground, pecked, } \\
\text { battered stone } \\
\text { (handstone) }\end{array}$ & 0 & 1 & 0 & 0.2 \\
\hline Cores (core tool) & 1 & 0 & 1.07 & 0 \\
\hline Flakes & 2 & 18 & 2.15 & 3.56 \\
\hline Chips & 1 & 19 & 1.07 & 3.75 \\
\hline Ceramics & 0 & 2 & 0 & 0.4 \\
\hline Faunal remains & 9 & 145 & 9.7 & 28.65 \\
\hline Marine shell & 1 & 0 & 1.07 & 0 \\
\hline Burned clay lumps & 79 & 321 & 84.95 & 63.44 \\
\hline TOTAL & 93 & 506 & 100.00 & 100.00 \\
\hline
\end{tabular}

The only tools recoverea from the excavation areas were (1) a core tool from 41 WY71 and (2) a handstone fragment from 41wY72. Neither is indicative of a specific time period. The two ceramic sherds located at $41 W Y 72$ indicate a late prehistoric affiliation, but no precise dates can be assigned.

The burned clay lumps recovered from the excavations at sites 41 WY71 and 41 WY 72 appear to indicate 
possible hearth activity areas although no definite features were encountered. At 41WY71, operation Area VII, there is a concentration of burned clay lumps present in strata I and II. These appear to be grouped around a tree root although no distinct outline could be discerned. Also present in these two strata are charcoal flecks and one tertiary flake, but no other associations were noted. At 41WY72, operation Area II, there is a substantial quantity of burned clay lumps present in strata III-VII with lesser amounts present in strata II, VIII and IX. The burned clay is scattered throughout the matrix in each stratum and no distinct features are discernible. Associated materials include charcoal flecks in strata III, VI and VIII, two tertiary flakes in stratum III, one decorticate chip and the two sandy paste sherds in stratum VIII.

Faunal materials are present in minimal amounts at 41 WY71 in Operation Area IV. The greatest concentration of bones is in 41 WY72 in Operation Area II, particularly in strata III and IV with lesser amounts present in Strata II, V, VI, VIII and IX. When the densities of bone and burned clay in these strata are compared, a correlation between the two is seen. In stratum I the amounts are equal. Then, in strata III and IV both categories show a marked increase which is followed by a marked decrease in strata $V$ through IX. Minimal amounts of bone were identified from operation Area IV, Stratum III, and from operation Area VI, Stratum III. Marine shell is represented by one small fragment at 41 WY71 from operation Area IV, Stratum III.

Tables 10 and 11 summarize the lithic debitage recovered from 41 WY71 (3) and 41WY72 (37). Table 10 summarizes the characteristics for the twenty tertiary flakes recovered from the two sites. Two of these flakes were recovered from 41WY71; one from operation Area I, Stratum III, and one from operation Area VII, Stratum III. The remaining eighteen were recovered from 41 WY72 from the following operation areas and associated strata: Operation Area I, Strata III (2) and IV (1); Operation Area II, Stratum III (2); Operation Area IV, Stratum IV (1); Operation Area V, Stratum III (1); operation Area VI, strata II (2) and III (8); and operation Area VII, stratum III (1).

An overall tertiary origin for the flakes from both sites suggests that they generally originated during the final stages of lithic tool manufacture. A relative concentration of flakes which was noted from operation Area VI, Strata II and III, may indicate a specific activity area. Chert was apparently the most available and/or desirable material represented by 100 percent at $41 W Y 71$ and 83.33 percent at 41WY72. Platform types 


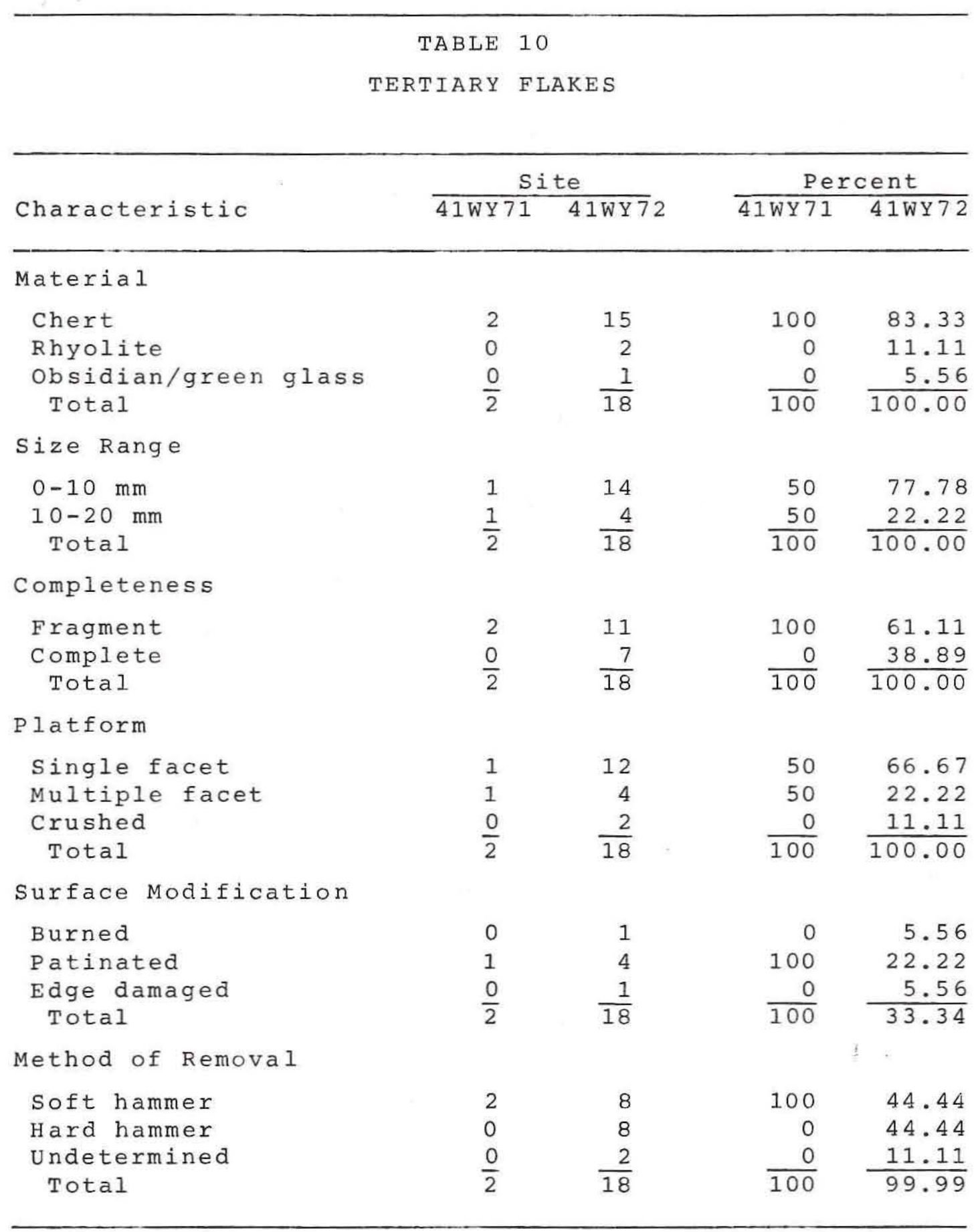


represented at 41 Wy 71 include one single-facet flake (50\%) and one multiple-facet flake (50\%). At 41WY72, platform types represented include 66.67 percent with single-facet platforms, 22.22 percent with multiplefacet platforms, and 11.11 percent with crushed platforms. Method of removal is represented at 41 WY71 with 100 percent by the soft-hammer technique. At 41Wy72, method of removal is represented with $44.44 \%$ by the soft-hammer technique, $44.44 \%$ by the hard-hammer technique, and $11.11 \%$ by an undetermined technique.

Table 11 summarizes the characteristics for the twenty chips recovered from 41 Wy 71 (1) and 41 Wy 72 (19). The single chip located at 41 Wr 71 from operation Area IV, stratum $V$, is chert and is decorticate in origin. of the nineteen chips found at 41WY72, twelve (63.16\%) are chert, one (5.26\%) is a rhyolite, and six (31.58\%) are obsidian or green glass. Eighteen (94.74\%) of the chips identified at 41 WY 72 are decorticate, and one ( $5.26 \%$ ) is partially decorticate. As with the flakes, this percentage indicates that the chips are generally products of the final stages of lithic tool manufacture. A concentration of chips was also noted in Operation Area VI, Stratum III. This adds to the amount of lithic

TABLE 11

CHIPS

\begin{tabular}{|c|c|c|c|c|}
\hline \multirow{2}{*}{ Characteristic } & \multicolumn{2}{|c|}{ Site } & \multicolumn{2}{|c|}{ Percent } \\
\hline & $41 \mathrm{WY} 71$ & 41 WY 72 & $41 W Y 71$ & $41 W Y 72$ \\
\hline \multicolumn{5}{|l|}{ Material } \\
\hline Chert & 1 & 12 & 100 & 63.16 \\
\hline Rhyolite & 0 & 1 & 0 & 5.26 \\
\hline Obsidian/green glass & 0 & 6 & 0 & 31.58 \\
\hline Total & $\overline{1}$ & $\overline{19}$ & $\overline{100}$ & 100.00 \\
\hline \multicolumn{5}{|l|}{ Amount of Cortex } \\
\hline Partially decorticate & 0 & 1 & 0 & 5.26 \\
\hline Decorticate & $\underline{1}$ & 18 & 100 & 94.74 \\
\hline Total & 1 & 19 & 100 & 100.00 \\
\hline \multicolumn{5}{|l|}{ Surface Modification } \\
\hline Burned & 0 & 1 & 0 & 5.26 \\
\hline Patinated & 0 & 4 & 0 & 21.05 \\
\hline Edge damaged & $\underline{0}$ & $\underline{2}$ & 0 & 10.53 \\
\hline Total & $\overline{19}$ & $\overline{19}$ & $\overline{0}$ & 36.84 \\
\hline
\end{tabular}


material previously noted and further indicates that this may be a specific activity area. Surface modification was minimal for the chips.

A particularly significant aspect of the lithic debitage is the material recovered at 41 WY72 from operation Area VI, Strata III. One tertiary flake and six decorticate chips are of an olive green colored (Munsell Color comparison 5Y 4/3)) material which may be either obsidian or glass. A final identification of the material has not been made. However, the specimens have been tentatively identified as obsidian from the Pachuka region of Mexico by Dr. Thomas R. Hester (personal communication, June 11, 1981).

Terrestrial snails are represented by three different species: Rabdotus alternatus, Polygyra texasiana and Helicina orbiculata (in a decreasing order of occurrence). of the twenty-nine levels excavated at 41WY71, Rabdotus alternatus was identified in six (20.69\%) levels, polygyra texasiana in four (13.79\%) levels, and Helicina orbiculata in two (6.9\%) levels. of the thirty-nine levels excavated at 41WY72, Rabdotus alternatus was identified in fifteen (38.46\%) levels, Polygyra texasiana in eight (20.51\%) levels, and Helicina orbiculata in five (12.82\%) levels. The snail shells at both sites were scattered throughout the matrix except for one apparently natural concentration which occurred at 41 WY72 in Operation Area II near the bottom of the excavation.

Although the snail shells collected are only a representative sample, it is felt that this is an accurate reflection of the general trènd of occurrence. Determination of these trends for the snail shells present could be significant in understanding the past environmental setting of the area. Different types of snails can reflect environmental changes which may have had an impact on aboriginal adaptations. 
Day, D. William, Jane Laurens-Day and Elton R. Prewitt 1981 Cultural Resources Surveys and Assessments in Portions of Hidalgo and Willacy Counties, Texas. Prewitt and Associates, Inc. Reports of Investigations 15. Austin.

Hester, Thomas R.

1981 Conversation with Dr. Thomas R. Hester of The University of Texas at San Antonio on June 11 , 1981 .

Mallouf, Robert J., Barbara J. Baskin and Kay L. Killen 1977 A Predictive Assessment of Cultural Resources in Hidalgo and Willacy Counties, Texas. Texas Historical Commission, Office of the state Archeologist Survey Report 23 . 
APPENDIX II: Faunal Analysis

Dale Winkler 


\section{TAXONOMY}

All turtle specimens in these sites are shell fragments. The mud turtle has a distinctive blunt carapace rim. One specimen of an emydid turtle was found (also a carapace $r i m$ ) but is not generically ldentifiable.

The specimens of rabbits are assigned to sylvilagus on the basis of size. These teeth are approximately the

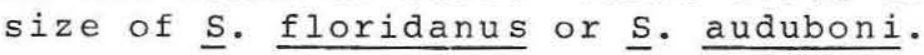

The specimen questionably referred to as carnivora is a highly fragmented tooth. This appears to be a canine about the size of a coyote or larger.

A single lower incisor, similar in morphology to Geomys bursarius, was found. This tooth is smaller than G. bursarius and may represent a smaller species, or more likely, a juvenile of bursarius.

\section{CONDITION OF BONE}

All specimens of bone and turtle shell are highly fragmented small pieces. No single bone element is complete. Many bones show signs of surface weathering before burial. Surface cracking of bone occurs after several months or a year. Examples of both mammal and turtle bones are burned. One specimen of mammal bone has an area modified with very fine grooves with chatter marks in them. This grooving is unlike most rodent gnawing and would be a very unusual occurrence if caused by a rodent. Two specimens from Unit-Level 2-3, 41wY72, are clumps of very small bone fragments in a carbonate matrix. These may have originally been carnivore scat or pellets.

\section{PALEOECOLOGY}

Mud turtles are common inhabitants of marshes and muddy ponds. Some species are tolerable of brackish water and are abundant in tidal marshes. Many specimens in these sites appear to be from relatively large individuals.

Gophers are common burrowing rodents in grasslands and prairies with sandy loam or loam soils. The remaining vertebrates in these sites are widespread in a 
varjety of habitats. The rattlesnake vertebrae are from medium to large individuals.

It is noteworthy that all vertebrates in these sites are medium to large species that may be possible prey species. No specimens could be assigned to the more common microvertebrates such as lizards or mice. It can be seen from Table 12 that Geomys is the most common and widespread mammal represented in these sites. Turtles are found in nearly every excavation. All specimens of rattlesnake are from one area and are probably from one individual.

All species of vertebrates in 41 WY 71 and 41 WY 72 are known today in or near willacy County and none are rare or unusual elements (Table 13). 


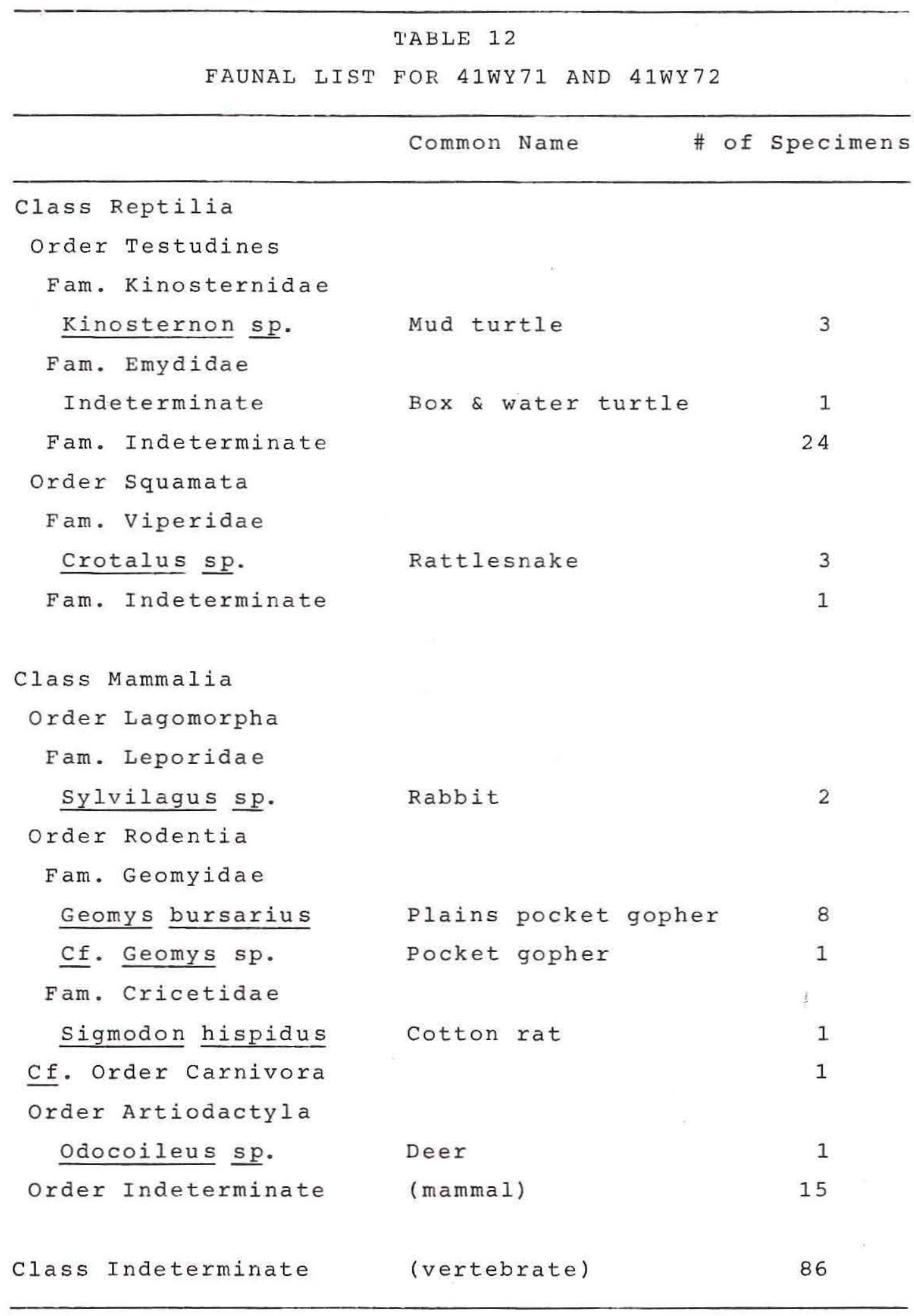




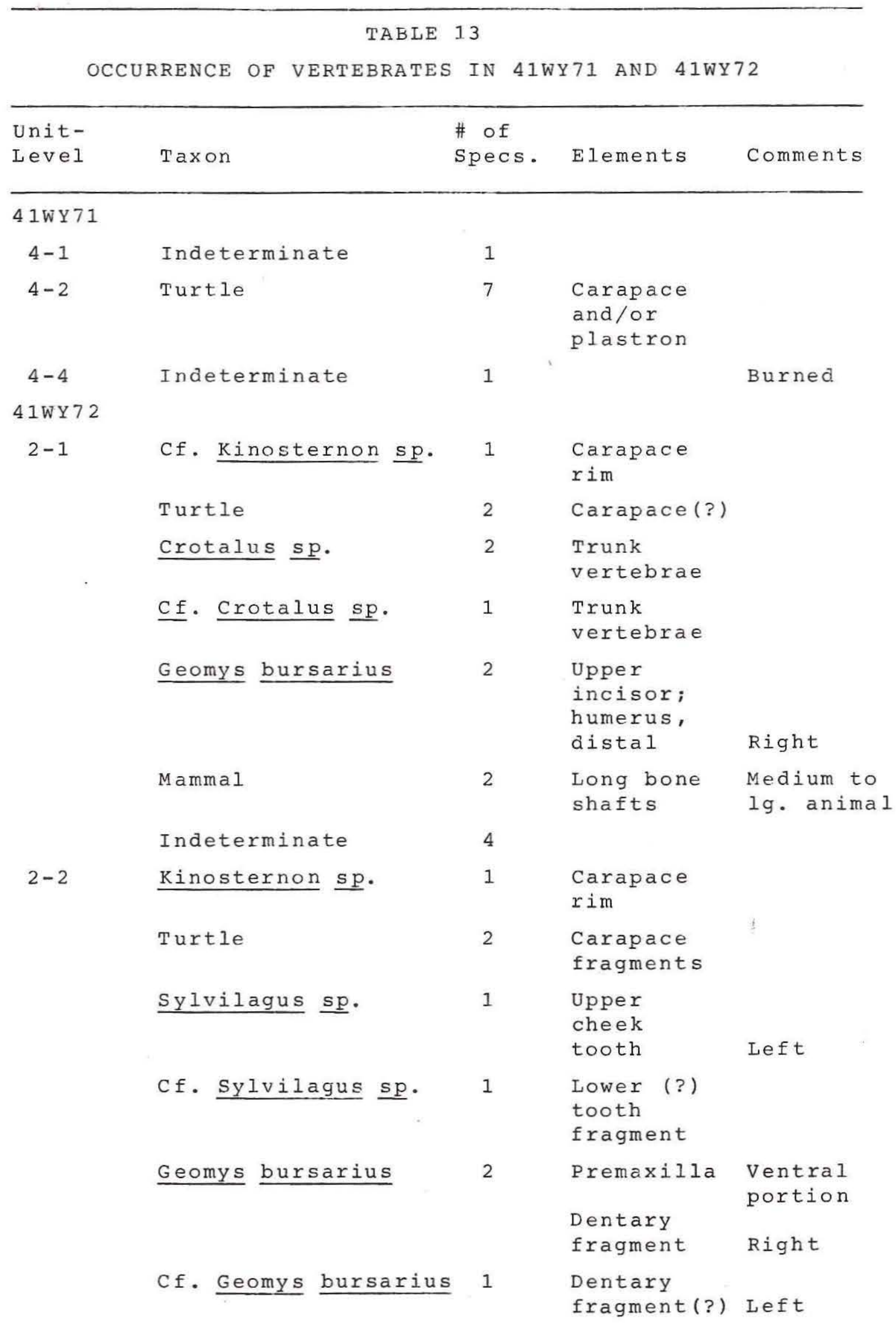


TA BLE 13, continued

\begin{tabular}{|c|c|c|c|c|}
\hline $\begin{array}{l}\text { Unit- } \\
\text { Level }\end{array}$ & Taxon & Specs. & $\begin{array}{l}\# \text { of } \\
\text { Elements }\end{array}$ & Comments \\
\hline \multirow[t]{5}{*}{$2-2$} & Cf. $\frac{\text { Sigmodon }}{\underline{\text { hispidus }}}$ & 1 & $\begin{array}{l}\text { Femur; } \\
\text { proximal }\end{array}$ & Left \\
\hline & Cf. Carnivora & 1 & $\begin{array}{l}\text { Canine } \\
\text { fragment (?) }\end{array}$ & Eroded \\
\hline & Mammal & 1 & $\begin{array}{l}\text { Tibia(?); } \\
\text { distal }\end{array}$ & $\begin{array}{l}\frac{\text { Geomys }}{\text { unfused }} \text {. } \\
\text { diaphysis }\end{array}$ \\
\hline & Mammal & 3 & - & \\
\hline & Indeterminate & 23 & - & \\
\hline \multirow[t]{11}{*}{$2-3$} & Cf. Kinosternon sp. & 1 & $\begin{array}{l}\text { Carapace } \\
\text { fragment }\end{array}$ & \\
\hline & Emydid turtle & 1 & $\begin{array}{l}\text { Carapace } \\
\text { fragment }\end{array}$ & \\
\hline & Turtle & 7 & $\begin{array}{l}\text { Shell } \\
\text { fragments }\end{array}$ & \\
\hline & snake & 1 & $\begin{array}{l}\text { Vertebra } \\
\text { fragment }\end{array}$ & \\
\hline & Cf. Geomys bursarius & 2 & $\begin{array}{l}\text { Scapula; } \\
\text { proximal } \\
\text { Humerus; } \\
\text { distal }\end{array}$ & $\begin{array}{l}\text { Right } \\
\text { Left }\end{array}$ \\
\hline & Mammal & 4 & $\begin{array}{l}\text { Long bone } \\
\text { shafts }\end{array}$ & $\begin{array}{l}\text { Medium } \\
\text { sized }\end{array}$ \\
\hline & Mammal & 1 & Tooth & $\begin{array}{l}\text { Highly } \\
\text { fragmented }\end{array}$ \\
\hline & Mammal & 1 & - & \\
\hline & Indeterminate & 2 & $\begin{array}{l}\text { Clumps of } \\
\text { small bones }\end{array}$ & $\begin{array}{l}\text { Possibly } \\
\text { coprolites }\end{array}$ \\
\hline & Indeterminate & 1 & $\begin{array}{l}\text { Bone } \\
\text { fragment }\end{array}$ & Burned \\
\hline & Indeterminate & 45 & - & \\
\hline \multirow[t]{3}{*}{$2-4$} & Turtle & 5 & $\begin{array}{l}\text { Carapace (?) } \\
\text { fragments }\end{array}$ & \\
\hline & Cf. Geomys sp. & 1 & $\begin{array}{l}\text { Lower } \\
\text { incisor }\end{array}$ & $\begin{array}{l}\text { Left; smaller } \\
\text { than G. } \\
\text { bursarius }\end{array}$ \\
\hline & Indeterminate & 2 & - & \\
\hline $2-5$ & Indeterminate & 3 & - & \\
\hline
\end{tabular}


TABLE 13, continued

\begin{tabular}{|c|c|c|c|c|}
\hline $\begin{array}{l}\text { Unit- } \\
\text { Level }\end{array}$ & Taxon & Specs. & $\begin{array}{l}\# \text { of } \\
\text { Elements }\end{array}$ & Comments \\
\hline \multirow[t]{4}{*}{$2-7$} & Mammal & 1 & $\begin{array}{l}\text { Distal } \\
\text { humerus (?) }\end{array}$ & \\
\hline & Mammal & 1 & ? & $\begin{array}{l}\text { Fine } \\
\text { grooves } \\
\text { with } \\
\text { chatter } \\
\text { marks. } \\
\text { ? Possibly } \\
\text { cut or } \\
\text { filed }\end{array}$ \\
\hline & Mammal & 1 & $\begin{array}{l}\text { Long bone } \\
\text { shaft (?) }\end{array}$ & \\
\hline & Indeterminate & 5 & - & \\
\hline \multirow[t]{3}{*}{$2-8$} & Turtle & 1 & $\begin{array}{l}\text { Carapace } \\
\text { rim }\end{array}$ & Burned \\
\hline & odocoileus sp. & 1 & $\begin{array}{l}\text { Metapoidal } \\
\text { shaft }\end{array}$ & $\begin{array}{l}\text { In three } \\
\text { pieces }\end{array}$ \\
\hline & Indeterminate & 1 & $\begin{array}{l}\text { Bone } \\
\text { fragment }\end{array}$ & Burned \\
\hline $4-2$ & Indeterminate & 1 & $\begin{array}{l}\text { Bone } \\
\text { fragment }\end{array}$ & Burned \\
\hline \multirow[t]{2}{*}{$6-2$} & Mammal (?) & 1 & $\begin{array}{l}\text { Long bone } \\
\text { shaft (?) }\end{array}$ & $\begin{array}{l}\text { Burned; } \\
\text { deer-sized }\end{array}$ \\
\hline & Indeterminate & 1 & $\begin{array}{l}\text { Bone } \\
\text { fragment }\end{array}$ & Burned \\
\hline
\end{tabular}


APPENDIX III: Constant Volume Sample Analysis

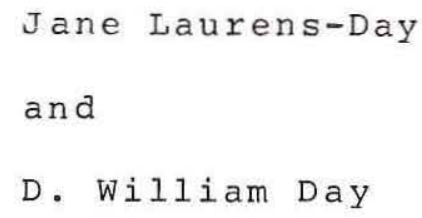


A limited constant volume analysis was performed on a sample of matrix collected from each of the recognized natural strata at both sites. The samples were collected from site 4IWY7I, Operation Areas I-IV and VII, and site 4lWY72, Operation Areas I, II and IV-VII. The limited time available for this study permitted only a cursory examination of the materials recovered.

Each sample examined consists of 800 cubic centimeters of matrix. The actual volume varied from an estimated 790 to 810 cubic centimeters due to the blocky nature of the soil. The soil was washed through a U.S. Standard sieve $(500$ microns, .0197 inches, Tyler equivalent 32 mesh) by using a gentle flow of water. The compact and blocky nature of the soil required 10 to 15 minutes of soaking for the majority of samples. After the soil was removed, the residue in the sieve was collected and thoroughly dried in an air-conditioned atmosphere.

Identification and quantification were carried out in three steps. First, a basic sorting of each sample was accomplished in order to remove rootlets. Second, a binocular microscope was used to identify the remaining debris; all samples were viewed under $60 x$ and $100 x$ magnification. Third, a record was made of the varieties and relative quantities of the materials encountered. After the inspection of the samples was completed, the residue was placed in vials and prepared for curation. The rootlets were discarded.

Categories of materials observed in the constant volume samples are lithic debitage, bone, burned clay, marine shell, terrestrial snail shell, seeds, charcoal and concretions. Table 14 presents a summary of the identified materials by strata according to the appropriate site and operation area designation. The following symbols are used to note presence or absence and relative quantities of materials recognized in each sample:

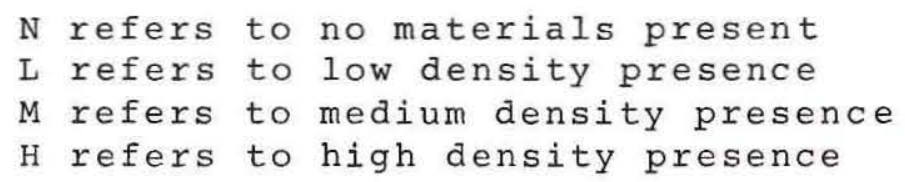

The relative quantities of materials are based on a judgmental assessment among all samples. A lack of time did not permit an accurate count of the various categories. In addition, the following symbols are used to supplement information for individual samples: 
TABLE 14

SUMMARY OF MATERIAL TYPES BY NATURAL STRATIGRAPHIC LEVELS

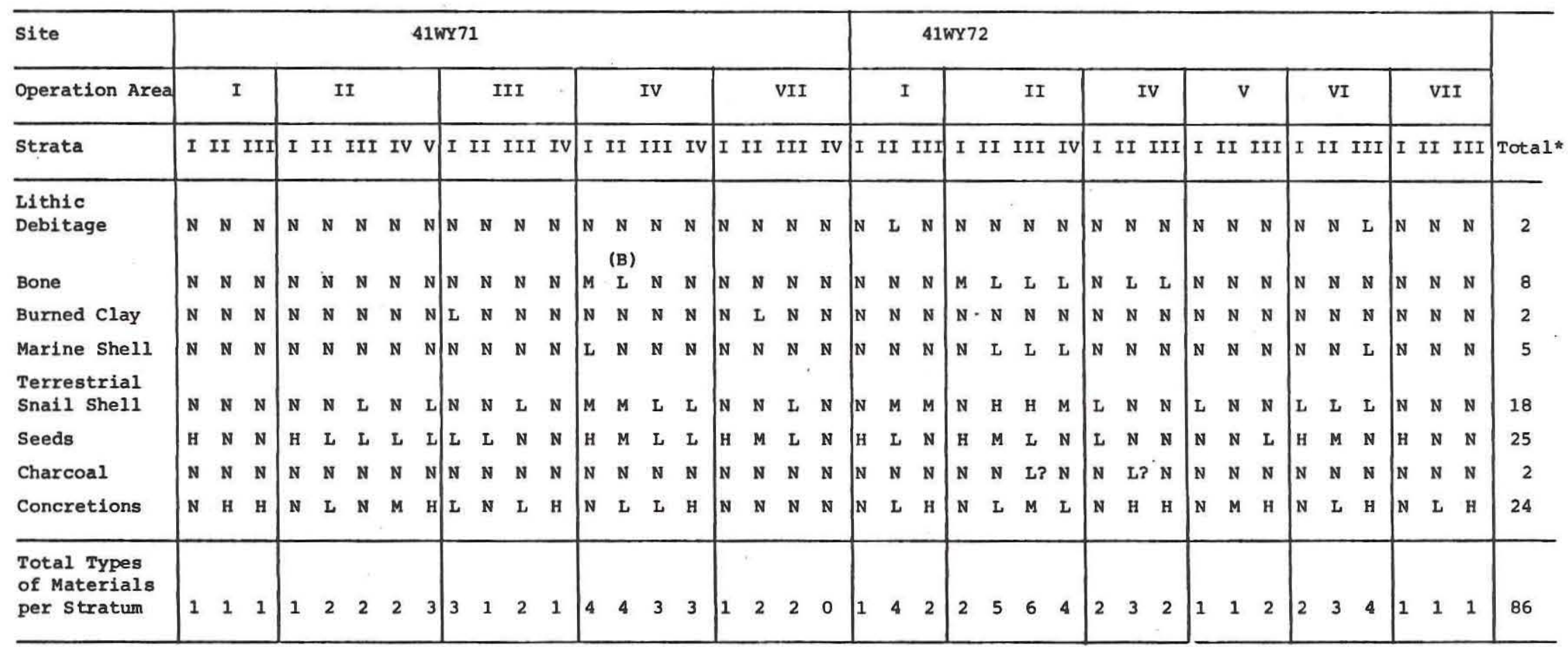

*Total = total number of strata per material type.

\author{
$N=$ no materials present \\ $L=$ low density presence \\ $M=$ medium density presence \\ $H=$ high density presence \\ $B=$ burned \\ $?=$ uncertain identification
}


(B): materials that are burned

(?): materials that could not be positively

identified

Only two specimens of lithic debitage, both from 4 WW 72 , were recovered. One is from operation Area I, Stratum II, and the other is from operation Area VI, Stratum. III. Both specimens are very small decorticate chips. No lithic debitage was observed in the samples collected at site 41 WY 71 .

Recovered bones consist of several very small unidentifiable fragments. The largest quantity (medium density) is from $41 W Y 72$, operation Area II, stratum I. Low densities of bones occur in the remaining three strata, II, III and IV. Bones were also identified in Operation Area IV, Strata II and III, of 41 WY72. Both samples are low density, and the bone in stratum II is burned. At site $41 \mathrm{WY} 71$ bone was identified in operation Area IV, Strata I and II (medium to low density respectively). None of these bones appeared to be burned.

Burned clay was identified at 41WY71, operation Area III, Stratum I, and operation Area VII, Stratum II. Both samples are low density. No burned clay was identified at site 41 WY 72 .

Marine shells were noted at both 41 WY71 and 41 WY 72 . The majority of the shells are from 41WY72, Operation Area II, Strata II, III and IV, and operation Area VI, Stratum III; all are low density. Marine shells were also noted at 41WY71, Operation Area IV, Stratum I, also low density. All of the marine shells were identified as pelecypods with the aid of the binocular microscope. Their diminutive size precluded genus and species identification; however, they appear to be immature stages of either marsh or semele clams.

Terrestrial snail shells were observed in eight of the twelve samples collected from 41 WY71, and in ten of the nineteen samples collected from 41WY72. Snail shells occur in the following operation areas and strata:

41WY71: Operation Area II:

$$
\begin{aligned}
& \text { Stratum III; low density } \\
& \text { Stratum V; low density } \\
& \text { Operation Area III: } \\
& \text { Stratum III; low density } \\
& \text { Operation Area IV: }
\end{aligned}
$$




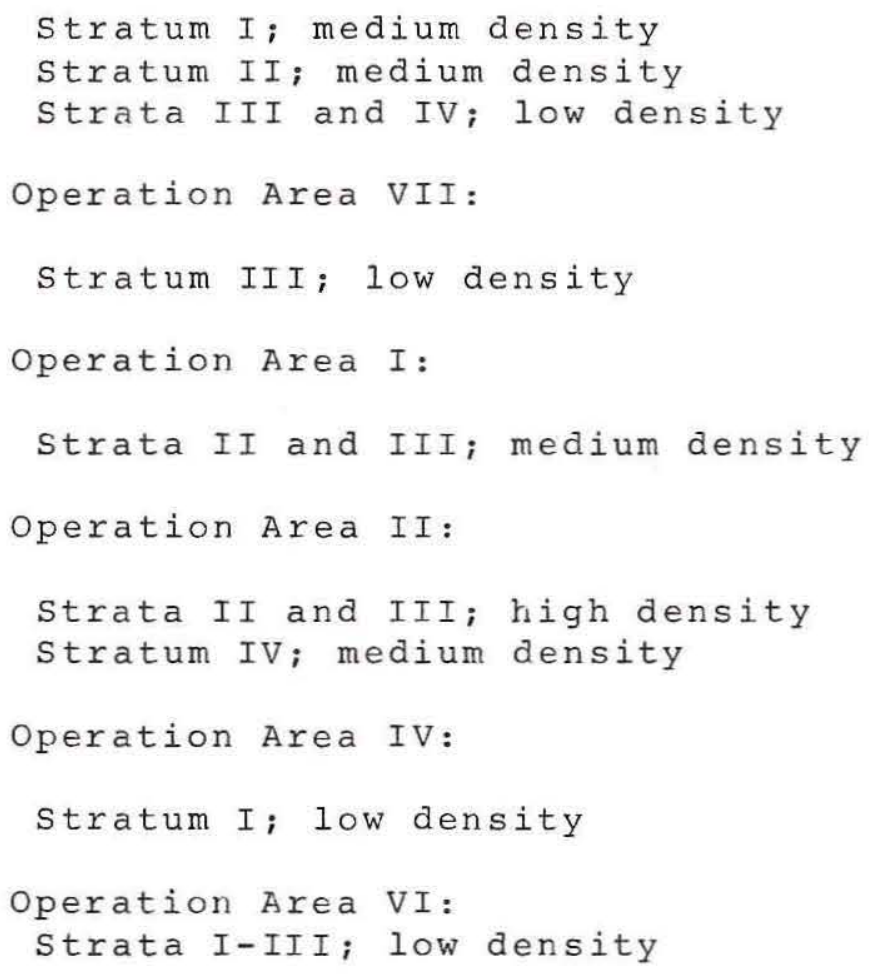

Identification was possible for most of the snail shells recovered from both sites. The larger species include the following: Rabdotus alternatus, Polygyra texasiana and Helicina orbiculata. Immature stages of these three forms are included.

A few small species were also found; these include the following: Helicodiscus sp., succinea sp. and Gastrocopta sp. Their diminutive size precluded positive species identification which cannot always be determined unless cross sections are obtained (Dr. Raymond Neck, personal communication, July 24, 1981).

Seeds were observed in fifteen of the twenty samples collected from $41 W Y 71$ and in ten of the nineteen samples collected from 41WY72. The operation areas, strata and relative densities of seeds are:

41WY71: Operation Area I:

Stratum I; high density

Operation Area II:

Stratum I; high density

strata II-V; low density

Operation Area III:

Strata I and II; low density 


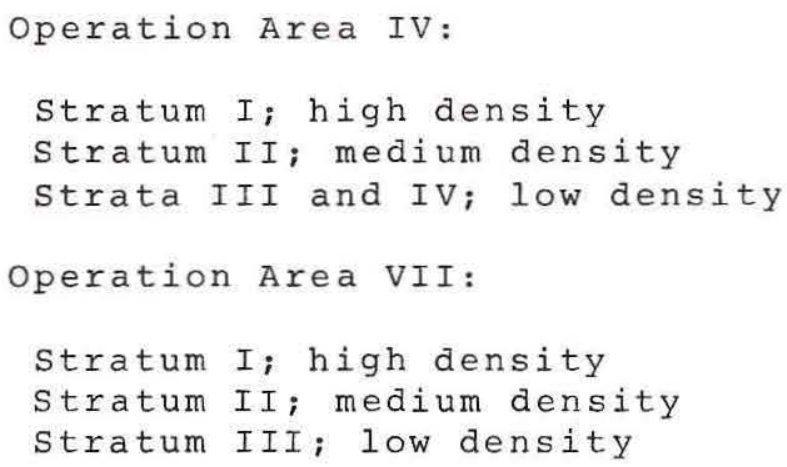

41WY72: Operation Area I:

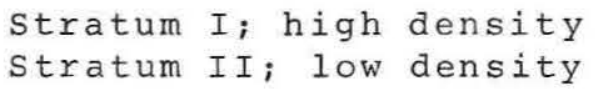

The relative amount of seeds is consistently high in density in the upper strata and consistently low in density to absent in the lower strata.

Possible charcoal noted is present only in the form of very small flecks and was observed only at 41 WY72, Operation Area II, Stratum III, and Operation Area IV, Stratum II. Identification of this material is questionable because of the small size of the flecks and minimal amount present.

Concretions were observed in eleven of the twenty samples collected from 41 WY71 and thirteen of the 
nineteen samples collected from 41WY72. The operation areas, strata and relative densities are:

41WY71: Operation Area I:

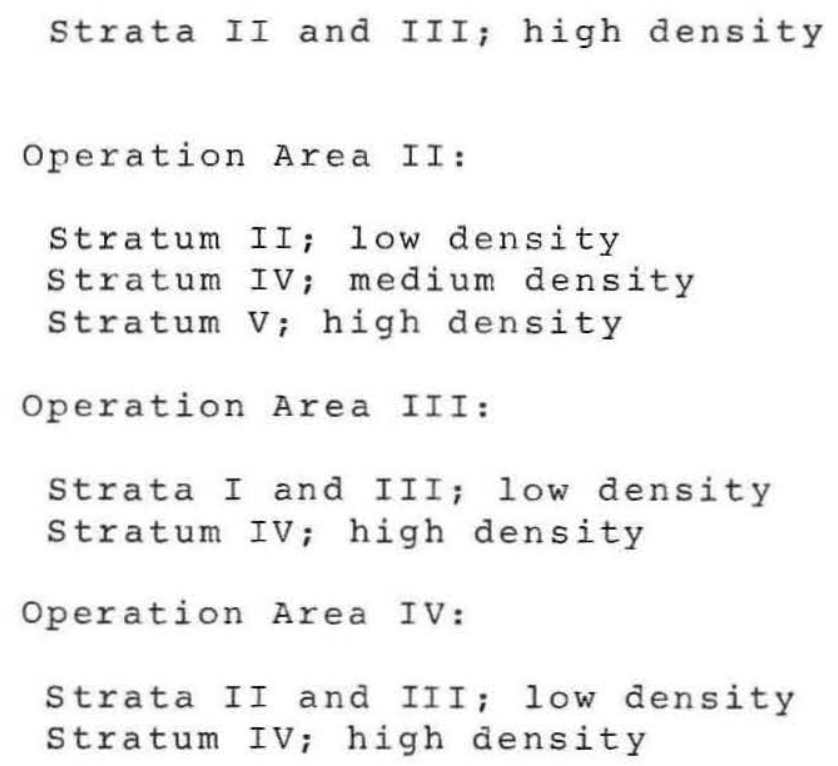


The relative amounts of concretions are consistently absent to low density in the upper strata and consistently high density in the lower strata. The majority of the concretions are calcium carbonate, but a few appear to be hematite.

The materials observed which may be identified as being associated with cultural activities include lithic debitage, bones, burned clay ana charcoal. These materials occur mainly in strata II and III, with some materials occurring in stratum $I$ and a minimal amount occurring in stratum IV. This trend correlates with the materials retrieved from the coarse screen during the excavations (see Artifact Analysis, Appendix I).

This basic limited analysis has shown that microscopic materials can be retrieved from sites in the Rio Grande Delta. Information such as this can aid in delineating and identifying specific areas of cultural activity and in environmental reconstruction. However, more detailed analyses are necessary to determine specific information on past environmental constructs and how they might relate to aboriginal lifeways.

This type of study could be quite helpful in that it could (1) supply specific environmental and cultural information which might not be obtainable from standard excavation data, and (2) add to the information already obtained from the excavations. It is suggested that future excavations in the region be planned in such a way as to allow for appropriate detailed analyses to pursue this aspect of investigation.

\section{REFERENCES CITED}

Neck, Raymond

1981 Interview with Dr. Raymond Neck of Texas Parks and Wildlife Department, Austin, on July 24 , 1981 . 